\title{
AN INTRODUCTORY DISCUSSION OF CRIMINOLOGY AND SOME OF ITS COMPONENTS
}

\author{
BURKE M. BARKER*
}

\begin{abstract}
In this article Professor Barker discusses the development of criminological thought, the constitutional factors in crime, the mental aspects of crime, and some sociological factors in crime in an attempt to explain in a rational way the phenomenon of crime.
\end{abstract}

In any general discussion of Criminology and its parent, crime, it is important to create categories for the limited purpose of aiding the understanding of the whole, component by component. The classification which follows is commonly used by many criminologists and is intended to aid the reader in any search of the literature which he may care to make for his own purposes. The order of treatment here will be: (1) development of criminological thought, (2) constitutional factors in crime, (3) mental aspects of crime and treatment, and (4) some sociological factors in crime. Of necessity, the attention paid to each of these components will not be as far-reaching as the magnitude of the literature would allow.

\section{The Development of Criminological Thought}

The development of modern criminological thought can justifiably be said to have commenced with the founding of statistical science in the 17th Century. Sir William Petty (1623-1687) drew attention to the value of a quantitative record of criminal activity as did Bentham in 1778 when he called for a statistical record of convictions for crime to be kept by the courts. In Bentham's view this "political barometer" would be of great value to the legislator in assessing the effects of legislation. It was however in France that the first systematic collecting of statistics relating to criminal activity was undertaken. The year 1827 saw the first annual report of criminal statistics published in that country. This 1827 report covered the year 1825 and these reports have continued without significant interruption until the present time. ${ }^{1}$

In England the first statistical information concerning crime and related to other social statistics such as population was published in 1810 . Since that time successive improvements have been made in English Criminal Statistics and the important publications in this area now consist of: Criminal Statistics England and Wales, Statistics Relating to Crime and Criminal Proceedings, Reports of the Commissioners of Prisons, Reports of the Commissioner of Police of the Metropolis, Reports of the Children's Department, Home Office, and specialized reports such as Offences relating to Motor Vehicles and Offences of Drunkenness.

The availability of this raw material stimulated the interest of men such as Guerry and Quetelet. Using the early French statistics these men carried out the first empirical studies of criminality.

- LL.B. (Sask.) Diploma in Criminology 1965 (Cantab.). Assistant Professor, Faculty of Law, The University of Alberta.

1 Sellin, The Measurement of Delinquency 7-8 (1964). 


\section{ANDRE MICHEL GUERRY (1802-1866)}

In 1883 Guerry published his "Essay on the Moral Statistics of France." The study was based upon the judicial criminal statistics of France for the year 1925 . He noted the regularity of crime and its regular variations between different areas of France. He also threw doubt upon previously assumed correlations between crime and poverty and crime and population density. With the publication of his "Essay" we see a significant attempt to free the study of criminality from the influence of an absolute morality.

\section{ADOLPH QUETELET (1796-1874)}

Adolph Quetelet published his "Essay on Social Physics" in 1835. Again his material was drawn from the French statistical publications. While judged from our vantage point certain of the observations which he made may appear commonplace, we should remember that their analytical foundation was unique. He observed certain correlations between age, sex, seasons, climate, economic inequality, occupation and criminality. He, too, commented upon the regularity in crime and stated that,"

We can count in advance how many individuals will soil their hands with the blood of their fellows, how many will be swindlers, how many prisoners, almost as we can number in advance the births and deaths that will take place. ... Here is a budget which we meet with frightful regularity-it is that of prisons, chains, and the scaffold.

Significantly, we find an echo of Quetelet's insight into the social causes of crime in The Challenge of Crime in a Free Society. ${ }^{3}$

\section{HENRY MAYHEW (1812-1887)}

Developments in England were somewhat slower and we must wait until Henry Mayhew published his London Labour and the London Poor in 1854, and The Criminal Prisons of London and Scenes from Prison Life in 1862 before we can say that any systematic effort to understand the nature of crime in that country was underway. Mayhew anticipated Lombroso when he rejected the theory of biological determinism in favour of a distinctly sociological explanation of criminality. In the words of Terence Morris: ${ }^{4}$

He [Mayhew] amassed an enormous amount of biographical material which went

far to demonstrate his main hypothesis, that crime was essentially a social phenomenon which was perpetuated by anti-social attitudes and ways of behaving being transferred from one generation to the next in a social setting characterized by poverty, drunkenness, bad housing, and economic insecurity.

It is to Mayhew and his collaborator Binny that we owe our only authoritative and non-official account of the early period of the new reformed penal system which followed the abolition of transportation in England. Mayhew was a succesful pioneer in the first-hand collection of data by interview and observation and, thus, his work is a valuable source of information about crime and its social setting in early Victorian London. His view that the persistent offender accounts for a major proportion of all criminal activity has been fully supported by 20 th Century Cana-

2 Quoted in Radzinowicz, Ideology and Crime, $A$ Study of Crime and its Social and Historical Context 29 (1966).

3 A report by the President's Commission on Law Enforcement and the Administration of -Justice, U.S. Government Printing Office, Washington, D.C., (1967).

4 Morris, The Criminal Area 61 (1957). 
dian experience. Further, it was Mayhew who posited that crime was the product of many social forces interpreted via the individual and not solely the consequence of moral laxity or an irresistible determinism.

\section{CESARE LOMBROSO (1835-1909)}

Cesare Lombroso, often called the father of modern criminology, was born in Verona, Italy. He studied medicine at Pavia and other Italian universities, and also at Vienna. His early medical research concerned itself with the study of cretinism and pellagra and this no doubt influenced his later theories based as they were to a great extent upon cranial measurement. His most famous work L'Uomo delinquente published first in 1876 contains the substance of his life's work. Although he was to modify his basic postulates under the impact of later criticism, it is the earlier form of his theories as to the causes of criminality for which he is remembered.

According to Lombroso the born criminal is a distinct anthropological type fated to commit crime. He is characterized by

Certain malformations of the skeleton and the skull, in particular cranial and facial asymetry, as well as by other physical stigmata of degeneration: an under or oversized brain, a receding forehead, high cheek-bones, squinting eyes, bushy and prominent eyebrows, a twisted nose, big ears, a projecting or receding jaw, scanty beard as contrasted with the general hairiness of the body and overdeveloped arms. In addition to these physical stigmata, he noted a lack of moral sense, vanity, cruelty, idleness, the use of a criminal argot, a specific nervous insensibility to pain, with contempt of death and suffering, and, finally, an inclination for tattooing. ... This congenital criminal, this moral imbecile, is an atavistic type, i.e. he represents a reversion to earlier primitive, human types or even to pre-human ancestors of mankind with cannibalistic instincts. 5

In later years as he extended his research over more cases Lombroso modified his views and admitted that, in perhaps two criminals out of three, environmental factors may be important. His theory has been attacked on many grounds, but chiefly because he failed to make use of adequate control groups from the non-criminal population. It was Dr. Charles Goring, an English prison doctor, who by use of the control group technique concluded that there was no evidence of the existence of the criminal type. Goring's research on the subject is considered by most to have conclusively refuted Lombroso's theory.

The real contribution of Lombroso and his students, Ferri and Garofalo, was to challenge the notion that crime could only be understood on a moral and not a scientific basis. In their view crime was caused by natural phenomenon and should be studied on that basis. This is the foundation of modern criminological studies. Of particular importance was Lombroso's focusing of attention upon the individual criminal. From this has flowed all useful criminological research.

While Lombroso's theory has been largely refuted by research carried out in Europe and North America, it still maintains a hold among individuals concerned to maintain a particular social system. The static nature of the theory provides a rationalization and an escape from the frustration caused by the continuing failure to prevent the growth of criminal activity. It also provides an escape from the disturbing implication that crime is the product of a particular social system.

5 Mannheim, Comparative Criminology 215-216 (1965). 


\section{ENRICO FERRI (1856-1929)}

\section{Enrico Ferri has been referred to by Sellin as:}

One of the most colourful and influential figures in the history of criminology ... the acknowledged leader of the so-called positive school of criminal science, a highly succesful trial lawyer, member of Parliament, editor of the socialist newspaper Avanti, indefatigable public lecturer, university professor, author of highly esteemed scholarly works, founder of a great legal journal and a tireless polemicist in defence of his ideas. ${ }^{6}$

He was born at Mantua and studied law at the University of Bologna. In 1879 he went to Turin to study with Lombroso. Later, he went to Paris to conduct a thorough analysis of the French criminal statistics covering the years 1828 to 1878 . In his analysis of these statistics he was particularly concerned with the social factors which he believed were vital to any explanation of the criminal activities which the statistics represented. It is thus plain that Ferri did not conceive of criminality as solely an anthropological function.

In his writings Ferri is most noted for his advocacy of the theory of multiple causation, his opposition to the jury except in criminal trials, ${ }^{\text {i }}$ and his opposition to the death penalty.

Any discussion of the work of Ferri must include some comment upon the classical and positive schools of criminal science. The chief characteristic of the classical school as represented by Beccaria, Romilly, Feuerbach (the principle of legality), and Bentham was a concern with the reform of criminal procedure and a desire to create an objective equation between crime and punishment. They had little concern about the individual offender.

In the words of Hermann Mannheim," the positive school "came into being largely in opposition to the classical school [and] it is in fact the first coherent system of criminological thought ever constructed." Referring further to Mannheim:

In the field of criminology proper, (a) the positivists took over Comte's idea of the progress of scientific thought from the theological to the metaphysical stage, and from there to the scientific or positive stage. This implied the complete divorce of science and law from morals; the priority of science; the repudiation of free will and moral responsibility, which later had to be replaced by the legal and social responsibility of the criminal, as the idea of guilt had to be replaced by that of dangerousness (periculosita) and its subjective elements (temibilita); (b) the attempt of the classical school to construct an equation between crime and punishment had to be replaced by an equation between the individual criminal and his treatment; (c) therefore, the individual criminal had to be studied by means of scientific quantitative observation of facts, and the effect of treatment by way of experimentation. The legal nature of the crime committed was comparatively unimportant. The classical school, .... wanted to reduce punishment, the positive school wanted to reduce crime by effective treatment of the offender in accordance with his needs. ${ }^{9}$

6 Mannheim (ed.), Pioneers in Criminology 5 (1960).

7 The jury system was abolished in Italy by the Fascist government and has not been restored with the demise of the Fascists. "The present Constitution has re-established the principle of the direct participation of the people in the administration of justice' (Art. 102); but since according to Article 111 of the same Constitution all judicial decisions without exception must include a reasoned opinion, it has been held that this unqualified constitutional provision prevents the reintroduction of the unreasoned jury verdict. Thus the decisions of the Courts of Assizes must be fully reasoned today in fact and in law, and appeal is granted against any part of them. Perhaps this was a wise move, since the traditional jury system in which the jurors were called on to judge without giving the reasons for their verdict, seems to have been fashioned as experience has borne out-for the very purpose of encouraging the juror to judge unreasonably: and so, rather than the faithful expression of social conscience, their verdict often appeared to be the triumph of pure pression of social conscience, their verdict often appeared to be the triumph of pure susceptible to appeal." Piero Calamandrei. The Crisis in the Reasoned Opinion in E.L. London (ed.), The Law as Literature 685-686 (1960).

8 Op. cit. supra, n. 5, at 221 .

$\theta$ Id., at 222. 
This system of social defence ${ }^{10}$ with its neutral morality, its emphasis upon the protection of the community, and its indifference to the principle of legality which would allow anticipatory measures to be taken in regard to potentially offending individuals inevitably provoked powerful opposition. While the positivist program has enjoyed a noticeable measure of legislative support, the strength of its opposition has led to a compromise in the field of penology. This compromise takes the form of the "double-track" system so evident in the sentencing of the Canadian courts. This system sees the courts attempting to equate the sentence of the individual with the nature of the offence, and at the same time providing in the sentence some treatment content. Retribution and rehabilitation side by side typify this "double-tracking" which will doubtlessly continue until we have an unreserved adoption of the indeterminate sentence.

That the moralizing nature of the views of the classical school, with its assumption of absolutes derived from Platonic influences, ${ }^{11}$ is incompatible with the insights of modern criminology is without question. If we accept Comte's view of the progression of scientific thought and if we also view criminology as a science, we can place our present position as midway between the metaphysical and the scientific on his continuum theological-metaphysical-scientific. The farther we move into the valuefree area of scientific inquiry, the more irrelevant will be the classical dependence upon absolutes. In its place the relativity of values and their continued modifictaion by time and circumstance will be the subject of our research and the basis of our penal policies.

\section{RAFFAELE GAROFALO (1852-1934) ${ }^{12}$}

Garofalo was born in Naples and over the years he became a lawyer, magistrate, and professor of criminal law. While he was an important advocate of the positivist doctrines, he did not accept the views of Lombroso and Ferri completely. In particular his efforts to formulate an extra-legal definition of crime placed him in opposition to the rejection of moral responsibility, an important tenet of the positivists. Garofalo sought for an absolute standard and at the same time he recognized faintly that the growing refinement of moral sentiments made the achievement of such a standard difficult.

\section{GABRIEL TARDE (1843-1904)}

Tarde was for 15 years a provincial magistrate in the village of Sarlat, France, his birthplace and home. It was here that he began the formulation of the theories ${ }^{13}$ which make him of interest to the criminologists (those kings without a country). Tarde left Sarlat to become the director of the Bureau of Statistics in the Department of Justice in Paris. In his writings he laid great emphasis on the social origins of crime and he did much to point out the weaknesses in Lombroso's anthropological theories of crime causation. While Tarde placed great emphasis upon the social origins of crime, he also attempted to demonstrate the importance of

10 Ancel, Social Defence $88 \mathrm{ff}$. (1965) for an analysis of the social defence doctrine.

11 For a discussion of the question of absolutes see: Jerome Frank, Law and the Modern Mind 11 ff. (1963).

2 Op cit. supra n at 220-221.

13 Tarde's publications include Comparative Criminology (1886) and Penal Philsophy (1890). 
personal choice and the element of chance in a criminal career. Accepting as he did the influence of personal choice in crime, moral responsibility then became significant. However, he was aware of the extraneous influences upon the individual which pressed upon him when called upon to choose. To Tarde, the crux of penal philosophy was the problem of moral responsibility. He considered two factors essential to determine the responsibility of the criminal. The first was the degree of ethical conditioning imposed upon the individual and retained by him, and the second was the degree of familiarity of the individual with the norms of the society in which he lived. If either or both of these factors was impaired in the individual, he could not be considered responsible for his crime.

It was Tarde who in some measure anticipated present movements towards the restriction of the criminal court function to decisions of guilt or innocence only. He also distrusted the jury. He deplored the fact that judges acted as both civil and criminal magistrates and suggested that the two forms be clearly distinguished so that the judges could serve in only one field. He saw the necessity for a special school for criminal magistrates to ensure better administration of the criminal law. ${ }^{14}$ Unlike Albert Camus, ${ }^{15}$ Tarde believed firmly in the deterrent effect of capital punishment and advocated its continuation.

\section{SUMMARY}

It was inevitable that the methodology of the physical sciences would have a great appeal to those men interested in unlocking the secrets of man the individual and man in society. In the realm of crime, the restriction on the freedom to verify by experimentation has of course limited the pace of enquiry but, it has not made it impossible, as the work of the pioneering criminologists has demonstrated. In particular, we owe to the Italian positivists "virtually every element of value in contemporary criminological knowledge."

\section{Constitutional Factors in Crime}

In the search for the causes of crime, the criminologist must begin somewhere and this means that he must make some assumptions. The assumption most commonly made is that crime is the product of constitutional, environmental, and psychological forces acting either singly (unlikely) or in having combinations upon the individual. While the intensity and magnitude of these forces are not presently subject to pre-

14 An interesting provision for the mandatory training of English Justices of the Peace is found in 5.17 of the Justice of the Peace Act, 1949, 12, 13 and 14 Geo. 6, c. 101 . This section provides that it shall be the duty of every magistrate's court committee, This section provides that it shall be the duty of every magistrate's court committee, in accordance with arrangements approved by the Lord Chancellor, to make and In a White Paper. The Training of Justices of the Peace in England and Wales, H.M.S.O. (1965), Cmnd. 2856, it was announced that compulsory training will be introduced for all Justices of the Peace appointed after the 1st of January, 1966. Among other things the Paper emphasizes that the purpose of the training is to acquaint the things the Paper emphasizes that the purpose of the training is to acquaint the puplls with the various courses which may be taken in dealing with offenders so and the other methods of treatment which they may use, and their effect. The and the other methods of treatment which they may use, and their effect. The Lord Chancellor also hopes to introduce in the near future a scheme to make available a course of lectures and discussions on sentencing and the treatment of offenders
to all those who are newly appointed to judicial office (H.C., Vol. 751, Col. 1341) 1968 Crim. L.R. 54 .

15 Albert Camus, Reflections on the Guillotine in E.L. London (ed.) op. cit. supra, n. 7. 16 Leon Radzinowicz. In Search of Criminology 3 (1961). 
cise measurement, their presence is nevertheless real and we must deal with them as best we can, keeping in mind the high degree of overlapping between them. (See Diagram I.)

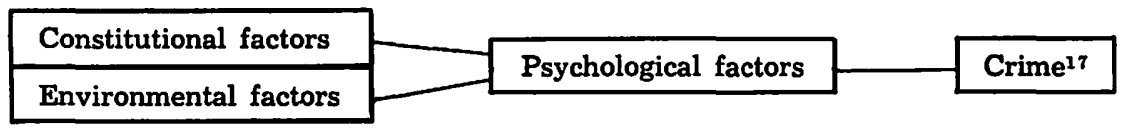

Diagram I: Inter-relationship of Factors Producing Crime.

The assumption made in this representation is that constitutional and environmental causes can only become operative after having passed through the mental mechanisms of the individual. ${ }^{18}$ The representation further takes account of the recognition by the biological sciences of the incorporation into the human organism of environmental forces.

When referring to constitutional factors in crime causation, I refer to those physical characteristics which predispose the offender to act in the way he does. These physical characteristics may be permanent or transitory in their duration. An example of a transitory criminogenic factor is drunkenness, while a permanent physical condition such as dwarfism may be a permanent predisposing criminogenic factor. Such evidence as there is relating to the constitutional predisposition towards criminal behaviour is presently found in studies concerning heredity, twins, endocrinology, and physique. The scientific study of these areas began with the early phrenologists, those men who tried to establish the relation between the skull, the brain and social behaviour. According to Franz Joseph Gall (1758-1828), the physical configuration of the skull and the structure of the brain were related to the individuals' propensities to certain forms of behaviour including criminal behaviour. It was, however, left to Lombroso to thoroughly popularize this anthropological explanation of criminal activity. Dr. Charles B. Goring (18701919), an English prison doctor, carried out the research which destroyed the validity of the anthropological theories. Goring's work, making use of statistical techniques developed at University College, London, by Pearson, and control groups, is summarized in his book The English Convict. ${ }^{19}$

\section{HEREDITY}

Many observers have noted the frequency with which criminality in offspring is matched with criminality in the parents or siblings and some have concluded that a propensity towards criminal behaviour is an inheritable characteristic. Studies of "criminal families" such as Richard Dugdale's The Jukes (1877), Estabrook's and Davenport's The Nam Family (1912) and Henry Goodard's The Kallikaks (1912) have been used in support of this conclusion. However, a closer examination of these works reveal that the evidence in support of the hypothesis is inconclusive. In Nigel Walker's words, "most delinquent children have lived with their delinquent parents or siblings long enough to acquire ways of life by imitation or some other non-genetic process of trans-

17 The suggestion for this diagram is found in op. cit. supra, n. 5, at 202.

18 While Newton may have removed God from the centre of the Universe, Darwin, Man, and Freud, Mind, in crime Mind remains the eye of the needle through which all must pass. See: Jacques Barzun, Science: The Glorious Entertainment 1 (1964).

19 H.M.S.O. Iondon (1913). 
mission."20 It was the conclusion of Cyril Burt that constitutional factors play a significant role in juvenile delinquency but it would be most incorrect to regard every criminal as the helpless victim of his inborn nature. ${ }^{21}$

\section{TWINS}

Nature or nurture is the oldest question in criminology, and one of the most important. The attempts to deal with it which have been the most successful have involved the studies of twins in which the degree of concordance or discordance in criminal behaviour of monozygotic (identical) and dizygotic (non-identical) twins has been tabulated. Monozygotic twins result from the fertilization of a single ovum which splits to form two independent embryos each embryo carrying an identical set of genes. These monozygotic twins are always of the same sex and blood group and are very similar in appearance. Dizygotic twins on the other hand, result from the simultaneous fertilization of two ova by two spermatozoa. These twins do not carry identical sets of genes and may consist of one male and one female, or two males, or two females. Their blood groups may or may not be the same and they may or may not resemble each other.

In terms of behaviour, twins which exhibit the same behaviour can be said to be concordant in respect to that factor. Twins which exhibit different behaviour are said to be discordant in respect to the behaviour factor. So, two twins possessing identical genetic complexions are said to be concordant in this respect. If monozygotic twins display a significantly higher rate of concordance in respect to the characteristic of criminal behaviour than dizygotic twins, this is some evidence that this characteristic is the product of genetic transmission. Medical research has disclosed that at least one form of abnormal behaviour is genetically transmitted and that is the symptom produced by Huntington's chorea. ${ }^{22}$ High rates of concordance for schizophrenia, idiopathic epilepsy, and alcoholism have also been found in the case of monozygotic pairs of twins. ${ }^{23}$ While twin births are rare and monozygotic twins rarer still, pairs containing a delinquent have been produced. Table I may be of assistance. ${ }^{24}$

Table I: Concordance Percentages for Pairs of Twins with at Least One Delinquent.

\section{Adult Pairs}

\begin{tabular}{cc} 
Monozygotics & Dizygotics of Same Sex \\
\hline $68 \%$ of 103 & $35 \%$ of 113
\end{tabular}

The criticisms which have been levelled at the tentative conclusions based upon such studies argue that the classification of the twins as monozygotic may be mistaken; that the observer included forms of criminality in the monozygotic group that they excluded from the dizygotic group (bias); and that the high rates of concordance in the monozygotic group was the result of environmental influences which were more marked in the monozygotic group than in the dizygotic group. The basis of this last criticism is that parents treat dizygotic twins differ-

\footnotetext{
20 Nigel Walker, Crime and Punishment in Britain 47 (1965)

21 Op. cit. supra, $\mathbf{n} . \mathbf{5}$, at 230.

22 Op. cit. supra, n. 20, at 48 . Also, see infra, n. 92

28 Id., at $48-49$

24 Id., at 49 .
} 
ently than their monozygotic twins because of marked difference in appearance.

As Walker ${ }^{25}$ points out, mistaken classification will most often see dizygotics classified as monozygotic thus reducing the concordance rate if anything. In regard to the second criticism one can only assume that the investigator was aware of the problem of bias and acted accordingly. The last criticism is of course the most substantial and can only be met by the use of monozygotic twins who have been reared in separate environments. Research along these lines has confirmed "that there is a marked genetic factor underlying measurable traits of personality, such as extraversion and neuroticism, and of course intelligence."

While Walker expresses the view that:

there is strong but not conclusive evidence based on unseparated twins for a partial determination of 'criminality' by genetic inheritance; and fairly conclusive evidence, based on separated and unseparated twins, for a similar determination of at least two personality traits. The onus of proof therefore seems to lie on those who wish to explain away the higher concordance rates for delinquency in monozygotics. ${ }^{27}$

Mannheim expresses a view more meaningful to the practical reformer when he says:

The practical significance of the whole controversy [nature v. nurture] lies only in part in the differences in treatment proposed by the followers of the opposing camps. It is clear that the environmentalists will put their faith more in the manipulation of the living conditions of the potential or actual criminal, while the believers in heredity transmission will recommend eugenic programmes. Perhaps more important than this are the dangers of a fatalistic attitude so easily assumed by members of the public who are always ready to regard an offender as incorrigible because 'it is in his blood'.28

The genetic transmission of constitutional qualities which predispose the individual towards various forms of criminal conduct can be reduced in incidence of genetically transferred feeble mindedness. However, before any such program is undertaken we must be in possession of more precise knowledge than we presently have of just what constitutional factors predispose the individual towards criminal behaviour. Futhermore, the nature of these qualities must be understood by the mass of the public if that public is to accept eugenic programs designed to reduce the incidence of criminal behavior. At the same time the question of environmental forces must not be ignored.

\section{ENDOCRINOLOGY}

Endocrine disturbances in the individual have been thought by some to be a contributing factor in criminality generally and particularly in the case of sexual offences. Schlapp and Smith ${ }^{20}$ in their book: The New Criminology (1928) attempted to explain the high crime rates among first American-born children of immigrants as the result of glandular disturbances brought on in the mother by the traumatic effects of immigration. This glandular imbalance was, the authors theorized, passed on to their offspring. When the disturbances subsided in the mother, subsequently born children were no longer afflicted. Hormonal medication and castration of the sexual offender which treatments assume an endocrinal

\footnotetext{
25 Id., at 50.

26 Id., at 50-51.

27 Id., at 51 .

28 Op. cit. supra, n. 5 , at 235 .

20 As referred to in Mainheim, supra, n. 5 at 235-236.
} 
basis for the prohibited conduct, have not shown impressive results or been free from controversy. ${ }^{30}$

\section{PHYSIQUE}

The relationship between body configuration and composition and personality as a subject of serious study is based largely upon the work of Ernst Kretschmer a famous German psychiatrist. $\mathrm{He}$ was able to establish an unquestionable correlation between certain body types and specific forms of mental illness. For example, he established a correlation between the athletic body type and schizophrenia.

Kretschmer went on to relate body types (somatypes) to criminality and in this endeavour may be considered the initiator of the work of Sheldon and the Gluecks in America. Sheldon's method of classifying body types is based upon the assumption that in every individual a certain type of tissue will be predominant and he created four body types or somatypes. They are: (1) The endomorph in which fatty tissue predominates. This type is given to food, drink, comfort, company and sleep. (2) The ectomorph in which skin and the nervous system predominate. This type is given to privacy, sensitive to pain, needs his sleep, and is youthful in appearance. (3) The mesomorph in which bone, muscle and sinew predominate. $\mathrm{He}$ is insensitive to pain and is given to movement and aggression. (4) The balanced type or that body build in which equal amounts of the features of the preceding types are found.

Using Sheldon's somotypes the Gluecks in 1956 gathered data which is summarized in Table II. ${ }^{31}$

\begin{tabular}{lcc} 
Somatypes & $\begin{array}{c}\text { Percentage of Persistent } \\
\text { Juvenile Delinquents }\end{array}$ & $\begin{array}{c}\text { Percentage of Matched } \\
\text { Non-Delinquents }\end{array}$ \\
\hline Mesomorphs & 60 & 31 \\
Endomorphs & 12 & 15 \\
Ectomorphs & 14 & 39 \\
Balanced Type & 13 & 15
\end{tabular}

Table II: Crime Rates Among Somatypes.

As can be seen the mesomorph predominates among the delinquents and the ectomorph among the non-delinquents.

\section{SUMMARY}

The role of the constitutional factors discussed is one of the potential forces which circumscribe the development of the individual man. Within the area of genetically possible growth, the forces of the environment are important. Whether these environmental forces will favour growth towards criminality or away from it depends upon the composition of the particular environmental pressures which come into contact with the genetic potentials of the individual. The initial plastic nature of the infant placed upon the potter's wheel of life dictates in part the ultimate form and coloration he will assume when taken from the kiln.

\section{The Mental Aspects}

The material which follows does not constitute a comprehensive treatment of the mental aspects of criminal behaviour. Rather, it is

30 Armstrong and Turner, Special Problem Groups in McGrath (ed.), Crime and Its Treatment in Canada 462 (1965).

31 Op. cit. supra, $n .20$, at 46. 
intended to convey some indication of the areas in which the criminologist should have a working knowledge if he is to perform his synthesizing function.

\section{MENTAL DISORDER}

Mental disorder as distinct from mental sub-normality is always characterized by a consistent failure on the part of the affected individual to meet the requirements of the reality with which he is surrounded. The line between periodic and consistent failure is notoriously difficult to draw and gives rise to shifting terminology and much imprecision in the literature. Thus, the interested individual has a large mearure of freedom in the construction of his thoughts upon the subject.

Attempts to isolate, stabilize, and quantify components of mental life have seen use made of the concepts of intelligence, emotional maturity, and persistence. Intelligence is the capacity to modify behaviour successfully to changing circumstances and to learn by experience. Emotional adjustment is the capacity to be reconciled to one's feelings towards things while persistence is the taking and maintaining of action prompted by intelligence or emotion or both. Scaling tests do exist which will allow the relative description of the individual personality in the terms mentioned. However, these tests can only serve as a guide in the assessment of mental life and ought not to be used alone.

From birth to age four a child's emotional needs are centered upon the mother and this is essential to normal development. From four to seven years, the child begins to form enduring relations with others and relations with the father become important. While this emotional pattern is unfolding, there is also a progressive development taking place in the child's intelligence. The child's success in his growth towards mental maturity depends upon emotional development and intellectual development keeping pace with each other. We know that his intelligence increases throughout childhood reaching a peak somewhere between the ages of fourteen and sixteen, and remains constant at that level until the latter half of his life when it begins to decline.

Of great interest to criminology is the fact that all behaviour has essentially an emotional root and that most emotional patterns are fully formed by age sixteen. Their modification after this time may be possible but difficult.

Mental disorders are commonly divided into two broad groups for the purposes of casual discussion-organic and functional. Organic mental disorder is dependent upon some distinct body disorder such as intoxicants or advanced syphilitic infection. Functional mental disorders are those disorders "for which no unmistakable physiological cause has yet been demonstrated." 32 They are recognized upon a psychological rather than a physical plane. Anxiety and hysteria are examples of functionally caused mental disorders.

There is a further subdivision of mental disorders into psychoses and neuroses. The neurosis does not deprive the sufferer from contact with reality while the psychosis does. The distinction between the two will be made plainer after a discussion of specific mental disorders.

32 See Stafford-Clark, Psychiatry Today $2 d$ ed. (1963) for the following discussion. 


\section{(a) Psychoses}

The psychoses which are of interest from a criminological point of view are the general paralysis of the insane (dementia paralytica) due to syphilitic infection, traumatic psychoses caused by accidents, encephalitis lethargica, senile dementia, puerperal insanity, epilepsy, intoxication psychoses, paranoia, paraphrenia, mania, and schizophrenia.

\section{(i) General paralysis of the Insane due to Syphilitic Infection}

The symptom of this psychosis is a general deterioration of the entire personality. The clinical symptoms are often preceded by anti-social behaviour such as thefts, frauds, forgeries, and violence committed without any attempt at concealment. These persons may be mistakenly held accountable for their conduct in the absence of clinical symptoms.

\section{(ii) Traumatic Psychoses caused by Accidents}

Cases have been reported where injuries to the brain have been followed by marked personality changes such as over-susceptibility to the effects of alcohol, excitability, and proneness to crimes of violence. The anti-social behaviour of the punch-drunk boxer typifies this form of psychosis.

\section{(iii) Encephalitis Lethargica (Sleeping Sickness)}

The fever associated with this psychosis produces an inflamation of the brain, "usually followed by serious and lasting after-effects and changes in physique, intelligence and character." 33 In the post-encephalitic period the sufferers may "commit thefts, assaults, acts of cruelty, or sexual misdemeanours. Little can be done except place them in special hospitals. . .."34

\section{(iv) Senile.Dementia}

This organic psychosis associated with changes in the cerebral blood vessels in middle or old age may result in "the impairment of the physical and mental faculties, emotional disturbances and the loss of control over sexual urges, coupled with growing suspicion of other people, [and] may provoke acts of violence or sexual assaults on children. ${ }^{35}$

\section{(v) Puerperal Insanity}

This passing psychosis affects the pregnant and the post-pregnant mother. The killing of her new-born infant by a mother while affected by this psychosis is treated not as murder but infanticide with the punishment being that alloted to manslaughter. This treatment of a recognized medical phenomenon is perhaps maintained because of a fear of an increase in infant killing if the threat of punishment was entirely absent. ${ }^{36}$

\section{(vi) Epilepsy}

Epilepsy is an organic psychosis frequently associated with criminality. The normal electrical activity of the brain may become extremely irregular and violent leading to unconsciousness, convulsions and uncontrolled bodily movement. Thus, the characteristic epileptic seizure.

\footnotetext{
38 Op. cit. supra, n. 20 , at 63.

34 Id., at 62 .

so Criminal Code of Canada, S.C. $1953-54$ c. 51, ss. 204, 570.
} 
However, this disturbance may be more modest and the epileptic characteristics hardly discernible. These epileptic seizures may be artificially induced but in the case of the true epileptic they are caused by relatively unknown internal stimuli. Damaged portions of the brain have been observed as the focus of the violent surges of electrical activity in some epileptics. It is known that certain infections and poisonings can lead to epilepsy. Where no discernible source can be found for the epilepsy it is known as idiopathic. Studies of twins seem to indicate that this type is commonly inherited by those of subnormal intelligence. Fatigue and stress increase the likelihood of seizures. Seizures may be controlled by barbituates and other drugs, and occasionally by surgery. Seizures can be followed by a state of automatism which may see the sufferer act in a variety of ways, some of which will be anti-social. Also, a seizure may be preceded by moods of depression or irritability possibly leading to unprovoked violent behaviour. These states may not be followed by any observable seizure and are known as epileptic equivalents. ${ }^{37}$

It is not known with any degree of certainty what proportion of criminals are epileptic. This is in part due to the great difficulty in diagnosis. The electro-encephalogram (E.E.G.) has been a great diagnostic aid yet abnormal E.E.G.'s are found in only $60-70$ per cent of all epileptics. ${ }^{38}$

\section{(vii) Intoxication Psychoses}

While we are told that intoxication leads to psychosis only rarely, ${ }^{30}$ when it does we may be treated to the situation found in $R$. v. Hartridge, ${ }^{10}$ where Hartridge shot his wife to death while he was in a highly intoxicated state. No apparent motive existed for the shooting and Hartridge made no attempt to conceal what he had done. In fact, the report of the rifle, according to his testimony, was the event which focused his mental processes upon the reality of the situation. He could remember nothing of the events surrounding the shooting. His defence of automation and the psychosis which it implies was denied by the Saskatchewan Court of Appeal in a comprehensive judgment delivered by Culliton, C.J.S. The Court was of the opinion that the cause of the psychosis was of paramount importance and in this was no doubt influenced by the wellknown reluctance of the criminal law to excuse responsibility in those cases where intoxication has been the offender's state.

Criminologically intoxication has four facets: ${ }^{41}$ (1) To what extent is intoxication per se a crime? (2) What influence does intoxication have upon the commission of crime? (3) What is the psychiatric significance of intoxication? (4) What is the reaction of the criminal law to offences committed under the influence of alcohol?

\section{Intoxication as a Crime}

Provincial legislation in British Columbia, Alberta, Saskatchewan, and Manitoba makes public intoxication per se a punishable offence. ${ }^{2}$ No attempt is made to distinguish between the intoxication of the alcoholic

\footnotetext{
37 Op. cit. supra, n. 20 , at 61.

38 Op. cit. supra, n. 5 , at 245 .

89 Id., at 246

40 (1967), 1 C.C.C. 346 (Sask. C.A.)

41 Op. cit. supra, n. 5, at 246.

42 Government Liquor Act, R.S.B.C. 1960 , c. 166 , s. 68 :

The Liquor Control Act, 1958, R.S.A. 1958, c. 37. s. 87 :

The Liquor Act, R.S.S. 1965, c. 382, s. 105 (1):

The Liquor Control Act, R.S.M. 1956, c. 40, s. 169 (3).
} 
and the non-alcoholic. As a contrast to the position of the four Western provinces, the recent decisions of American courts on the subject of public intoxication deserve attention. These decisions involve the application of legislation similar to the Canadian enactments. ${ }^{43}$

In Robinson v. California ${ }^{44}$ the Supreme Court of the United States stated:

It is unlikely that any State at this moment in history would attempt to make it a criminal offense for a person to be mentally ill, or a leper or to be afflicted with a venereal disease. A State might determine that the general health and welfare require that the victims of these and other human afflictions be dealt with by compulsory treatment, involving quarantine, confinement, or sequestraiton. But, in the light of contemporary human knowledge, a law which made a criminal offense of such a disease would doubtlessly be universally thought to be an infliction of cruel and unusual punishment in violation of the Eighth and Fourteenth Amendments.

The Court was dealing in Robinson with a provision of the California Health and Safety Code ${ }^{4 i}$ which made it a punishable offence to be addicted to the use of narcotics, and it held such legislation to be contrary to the constitutional provisions of the Eighth and Fourteenth Amendments.

Driver v. Hinnant ${ }^{46}$ saw Driver, a 59-year-old chronic alcoholic, convicted of public drunkenness contrary to a North Carolina Statute prohibiting such conduct. ${ }^{4 i}$ The Court of Appeals for the Fourth Circuit in setting aside Driver's conviction accepted chronic alcoholism as a disease, one of the symptoms of which may be the appearance of the sufferer in a public place in an intoxicated condition. In the Court's view the punishment of a person manifesting such a symptom is a "cruel and unusual punishment" and thus constitutionally forbidden. However, the Court was careful to point out that:

This conclusion does not contravene the familiar thesis that voluntary drunkenness is no excuse for crime. The chronic alcoholic has not drunk voluntarily, although undoubtedly he did so originally. His excess now derives from disease. However, our excusal of the chronic alcoholic from criminal prosecution is conconfined exclusively to those acts on his part which are compulsive as symptomatic of the disease. With respect to other behaviour-not characteristic of confirmed chronic alcoholism-he would be judged as would any person not so afflicted. 48

The problem of discriminating between those acts which are compulsive and symptomatic of chronic alcoholism and those which are not will come perilously close to the whole vexing question of the nature of criminal responsibility.

Easter v. District of Columbia ${ }^{49}$ saw the appeal Court re-iterate and approve the reasoning in Driver and underscore the significance of Federal legislation relating to alcoholism,,$^{50}$ in a situation analogous to the Driver case. However, in spite of the opinions expressed in Driver and Easter which opinions have as a common source the Supreme Court decision in Robinson, the Supreme Court of the United States has refused

43 See Faller, Criminal Law-Culpability of the Chronic Alcoholic, La.L.Rev. 27: 340 F'67.

44 (1962) 370 U.S. 660, 666 (italics added).

43 S. 11721.

46 (1966) 356 F. $2 d 761$ (4th Cir.).

47 N.C. Gen. Stat. 14-335 (1907).

48 (1966) 356 F. 2d 761, 764 (4th Cir.)

49 (1966) 361 F. 2d 50 (D.C. Cir.).

so The Rehabilitation of Alcoholics Act, 61 Sta. 744, c. 472 (1947). 
to extend the disease concept to the chronic alcoholic. ${ }^{51}$ This refusal was not unanimous and Mr. Justice Fortas and Mr. Justice Douglas both were of the opinion expressed in the words of Mr. Justice Fortas that:

The use of the crude and formidable weapon of criminal punishment of the alcoholic is neither seemly nor sensible, neither purposeful nor civilized.

Influence of Intoxication upon the Commission of Crime

While empirical evidence is scarce as to the criminogenic effects of alcohol certain of its effects upon common mental and physical functions are well known. Canadian Criminal Statistics contain no useful evidence as to the criminogenic effects of alcohol. We in Canada just do not know how often the consumption of alcohol leads to the commission of an offence other than cases of impaired and intoxicated driving.

Wolfgang's study of homicide in Philadelphia:2 found that in a sample of 588 cases alcohol was present in the blood of both the offender and victim in nearly two-thirds of the cases. Recent studies in the United States $^{53}$ and Britain ${ }^{54}$ have accumulated further evidence relating to alcohol and crime. The American study revealed that in the case of sex offenders alcohol was present in the offender in a significantly large number of occasions. Dr. Glatt in his research concluded that in a substantial minority of cases the consumption of alcohol by the offender was a contributing factor to the commission of the crime.

A dual approach should be maintained when dealing with the influence of alcohol upon crime. Offenders should be classified as alcoholics or those whose drinking is not characteristic of the alcoholic. Alcohol will in the latter case play only a transitory role in offence precipitation. On the other hand, alcohol consumption by the alcoholic is a residual characteristic and as such will continuously interfere with his repressive mechanisms, thus, opening more and broader paths to criminality in his case. A failure to differentiate between those offenders suffering from alcoholism and those who are not, can have chaotic consequences for the orderly development of appropriate reactions on the part of the criminal courts.

\section{Psychological Significance of Intoxication}

Three different types of drunkenness must be recognized when considering the psychological significance of intoxication. ${ }^{55}$ They are: normal drunkenness, pathological drunkenness, and chronic alcoholism. As the term suggests, normal drunkenness occurs occasionally in the normal person and may produce the expected disabilities in physical and mental capacities. Criminal conduct may occasionally result. Pathological drunkenness refers to the intoxication of those persons already suffering from some form of mental instability, head injury, epilepsy, mental defect, psychosis, or psychopathy. These persons are exceptionally prone to violence under the influence of even small amounts of alcohol. The

51 Budd v. California (1966), 87 Sup. Ct. 209 (U.S.)

52 Wolfgang, Studies in Homicide (1967), p. 22.

53 Gebbard, Gagnon, Pomeroy and Christenson, Sex Offenders (1965).

54 Glatt, 9 Brit. J. Delinq. (Oct., 1958).

s. Op. cit. supra, n. 5 , at 249-250. 
drunkenness of the chronic alcoholic ${ }^{56}$ leads in time to the hallucinations of delirium tremens with the consequent risk of violence. It is the drunkenness of this type which is characterized by the uncontrolled consumption of alcohol. The true alcoholic no longer has any freedom of choice in regard to his consumption of alcohol and it is this individual who poses a challenge of enormous magnitude to the present Canadian criminal administration. ${ }^{57}$

\section{Intoxication as a Defence}

The drunken offender provides a serious challenge to the security and consistency of the commonly held concepts of the mental constituent of the criminal act. In the interests of logical consistency any evidence of drunkenness which casts a reasonable doubt upon the existence of the mental ingredient of the offence ought to result in an acquittal. This does not in fact invariably happen when the defence of drunkenness is put forth. Very frequently, the implied "voluntary" nature of the drunkenness is substituted for the doubtful presence of the required mental state at the time of the actus reus. In this manner nominal allegiance is paid to the dual nature of the criminal act and minimal violence is done to our sense of rationality.

The persistent tension between moral forces seeing in drunkenness the mark of Cain, and those forces representing an increased awareness of the intellectually incapacitating nature of intoxication has woven the English and Canadian judicial pronouncements upon the subject into the bizare tapestry of Meade,,$^{38}$ Beard," Gallagher, ${ }^{, 0}$ George,,$^{11}$ Vandervoort, ${ }^{62}$ and Boucher. ${ }^{63}$

\section{(viii) Paranoia}

The fundamental characteristic of paranoia is the presence in the sufferer of an ordered and concrete persecution delusion. The concept of paranoia is based largely upon the work of Emil Kraepelin, a nineteenth-century psychiatrist. It is usually found among the middle-aged and elderly particularly elderly women.

This functional psychoses is of particular importance in violent crime.

53 Jellinek describes five main types of alcoholics. The Alpha alcoholic, a heavy and regular drinker without indications of habituation or addiction. The Beta alcoholic, a heavy and regular drinker who suffers from the toxic effects of his drinking to the point where this causes repeated drunkeness or a variety of physical disorders. The gamma alcoholic, a heavy and regular drinker evidencing a true dependence on alcohol. He is unable to control his intake and always proceeds to intoxication and the undesirable behavior which follows. The Delta alcoholic is characterized and the undesirable behavior which follows. The Delta alcoholic is characterized loss by drunken episodes than by the discomfort he experiences when he attempts alcoholic is a victim of one of a number of episodic types of alcoholism.

57 Armstrong and Turner point out that in Toronto in a 12 month period ending October 31, 1961, 18,280 persons appeared in court charged with being drunk in a public place contrary to the Liquor Control Act of Ontario. Approximately 8.700 public place contrary to the Liquor Control Act of Ontario. Approximately 8,700
individuals accounted for the 18,280 appearances. A maximum of 6,000 were appearing for the first time in the 12 months, 1560 appeared for a third or subsequent time: in McGrath (ed.), op. cit. supra, n. 30, at 432 .

s8 R. v. Meade, [1909] 1 K.B. 895; 78 L.J.K.B. 476; 2 Cr. App. Rep. (C.C.A.)

so D.P.P. v. Beard, $\{1920 \mid$ A.C. $479 ; 14$ Cr. App. R. 159 (H.L.)

bo A.-G. for Northern Ireland, v. Gallagher, [1961] 3 All E.R. 299; [1961] 3 W.L.R. 619 (H.L.).

61 R. v. George, [1960] S.C.R. 871; 34 C.R. 1; 128 C.C.C. 289.

62 R. v. Vandervoort, [1961] O.W.N. 141; 34 C.R. $380 ; 130$ C.C.C. 158 (Ont. C.A.)

(33 R. v. Boucher et al. (1962), 40 W.W.R. 663; 39 C.R. 242 (B.C.C.A.). 
Suspicion of sexual infidelity ${ }^{64}$ is a frequent expression of paranoia and may lead to violent conduct on the part of the sufferer towards the suspected partner.

Retaliation against the fancied persecutor is not unknown with M'Naghten's ${ }^{65}$ case providing a well known example. Daniel M'Naghten suffered from paranoia and he focused upon Robert Peel as his major persecutor. This ultimately led to his coming to London for the fixed purpose of assasinating Peel. Queen Victoria's fortuitous absence from London and Peel's consequent use of her carriage saved his life but cost Peel's secretary Drummond his for M'Naghten, believing that Peel was riding in his own carriage, shot and killed the unfortunate Drummond.

Paranoia may lead the sufferer to believe that the world is so hopelessly corrupt that he must kill his family and himself. It may also lead to extreme quarrelsomeness followed by the maintenance of pointless lawsuits. The presence of amorous delusions may see the sufferer embark upon hopeless projects of amorous conquest.

\section{(ix) Paraphrenia}

This is a general term inclusive of paranoia and schizophrenia. In paraphrenia the delusions are not so well organized. Being of a more transitory nature than the insane delusion, predictability of the sufferer's conduct is more difficult. This gives the violence of paraphrenia a more unsettling characteristic.

\section{(x) Manic-Depressive Psychosis}

This type of mental disorder sees an alteration between periods of excitement and depression, with occasional periods of sanity interspersed between swings. The phases may last for days or even weeks. Mannheim writes:

Crimes, especially of violence, and suicide will occur mainly in the depressive phase, whereas in the manic phase petty stealing, swindling and drunkenness offences are more frequent. Most homicidal attacks are made on members of the sufferer's own family for reasons basically similar to those of the religious paranoiac. ... Particularly severe attacks of depression and agitation occur in cases of so-called involutional melancholia, especially in women at or after the menopause and, though less often, in men in their fifties. ${ }^{66}$

Depression may be triggered by some force outside the individual (reactive depression) such as influenza or the use of sulphonamides. It may be endogenous with no ascertained external cause. Whatever the cause of the depression, suicidal behavior ${ }^{6 i}$ is often the result. A father destroying his family and himself or a lovers' suicide pact are the products of a deep depressive state. ${ }^{68}$

64 An example of the sexual suspicions of the paranoid came to the author's personal attention when acting on behalf of such a person involved in a maintenance dispute. His delusion, firmly held, was that his parapalegic elderly wife was participating in a sexual relationship with another man while he was away at work during the day. He related with obvious satisfaction the manner in which he had confirmed his suspicions. This was done by placing toast crumbs upon the counterpane of the matrimonial bed each morning prior to leaving for work. These crumbs were in a predetermined pattern, and any disturbance in them was duly noted upon his return at the end of the day.

65 An interesting account of some of the important non-legal factors in M'Naghten's case will be found in Mr. Justice Kaufman's judgment in U.S. v. Freeman (1966), 356 F. 2d 606 (2nd Cir.).

6c Op. cit. supra, n. 5 , at 251

c7 Criminal Code of Canada, supra, n. 36, s, 213. A successful suicide is an example of Dr. William's "unenforcebale crime."

is R. v. Hiborn [1946] O.R. 552; 2 C.R. 129; 86 C.C.C. 406 (Ont. C.A.). 
At the opposite end of the spectrum, mania will manifest itself in high, uncontrolled excitement sometimes leading to violence such as homicide which is a reflection of an excited desire to kill. The treatment for depression and mania is usually by way of drugs or electro-convulsion.

\section{(xi) Schizophrenia}

This is the most common and important form of functional psychosis. Various theories have been put forward as to its cause. Chief among these causal theories are heredity, psychic, and endocrine factors.

Schizophrenia is often dealt with under four categories. In Walker's ${ }^{69}$ words:

Commonest among young adults is hebephrenic schizophrenia, which seems to consist of disorder of thought. This is insidious in its onset, so that it may at first be dismissed as neurosis. A promising student may find it harder and harder to concentrate and think logically; he drifts off into vague metaphysical interests. Or may degenerate into a ceaseless joker: mild hebephrenics have become successful clowns or stage humorists through their ability to exploit their spontaneous silliness. Occasionally, in the early stages of the disorder, there is a sudden flare-up of sexual impulses, or of rage or terror, which may lead to anti-social behavior. The progress of the disorder sometimes halts spontaneously, more often under treatment. If it is not halted, symptoms such as hallucinations and withdrawal from reality manifest themselves.

In contrast in the catatonic, whose chief symptom is stupor and a resistant, negative attitude to attempts to induce purposive activity. Advanced catatonics will assume bizarre poses and maintain them for long periods. They may occasionally commit impulsive and brutal attacks, for example on doctors and nurses, but since the disorder is so easily recognized and leads so surely to hospital the public is usually protected from them. Paranoia is the most frequent form among the middle-aged or elderly, and especially among elderly women. The distinguishing symptom is a delusion of persecution which may drive the sufferer to flee into various parts of the country, and eventually to retaliate against his fancied persecutors. ... O Often the delusions take a sexual form. ...

[Lastly], . . the 'simple schizophrenia, without catatonia, hallucinations or delusions, but consisting apparently of a rapidly developing shallowness of emotion, irresponsibility and lack of will-power. .. . Women schizophrenics may become prostitutes. More spectacular, of course, is the solitary, quiet schizophrenic who suddenly commits a crime of violence, often involving sexually motivated mutilations, and not infrequently against his wife, mother, father or other relative with whom he is living at the time.

The essential features of all forms of schizophrenia are:

A complete withdrawal of the patient's personality into himself ('shut-in'-type) with a progressive deterioration and disorder of thought, emotions and conduct, flight into fantasy life, defects of judgment, peculiar mannerisms, delusions, and hallucinations. . . In most cases the illness begins between the ages of 15 and 25. ${ }^{70}$

It is obvious that this form of mental disorder will provide a wealth of anti-social acts. When these take the form of homicide the underlying cause is usually acknowledged. In the case of the mentally sub-normal 
their offences frequently take a sexual form. With the psychotics and the manic-depressives, acts of personal violence pose the greatest threat. ${ }^{71}$

\section{(b) Neuroses}

The world of the psychotic is so dominated by his fantasies that to him the ordinary laws of nature are no longer applicable. Reality is gone. The neurotic on the other hand is able to view the world as it is, but his ability to cope with its demands is markedly impaired. Neurotic symptoms do not include hallucinations or delusions and their beginnings are gradual and never clearly marked. Phychotherapeutic methods of treatment are usually employed although drugs may occasionally be used.

In the general population the presence of the various kinds of neurosis is very high: Among delinquents the available evidence indicates that neurosis is far more frequent than psychosis.

The uncommon incidence of neurosis in the prison population is probably explained by the nature of neurotic illness. In Mannheim's words:

If the individual has, unconsciously, to choose between neurosis and delinquency,

his choice may depend on the source of the conflict responsible for his difficulties.

If they are rooted in himself, he is likely to develop a neurosis; if, however, they are caused by other people, he is more likely to commit delinquent acts, but he may also take refuge in a neurosis as a defence against his aggressive impulses. The delinquent who is somehow deprived of his delinquent outlets may occasionally develop a neurotic symptom, especially if his victory over his delinquent tendencies was achieved through over-great self-control. ${ }^{72}$

The concept of the neurosis is usually based upon the Freudian analysis of unconscious inner conflict between the ego, the super-ego, and the mainly sexual and instinctive desires.. According to the Freudian analysis, this inner conflict is to be found in all persons. In most, the process of repressing the instinctual desires is done without difficulty. However, in some this process is excessively difficult, and produces an unconscious feeling of guilt and the need for self-punishment, hence, the neurosis. It is usual for the neurotic to confine himself to self-punishment but of

71 Walker, op. cit. supra, $n$. 5 , at 21 deserves to be set out when he refers to Evelyn Glbson's study (italles added)

Like many other crimes of violence, they [murders] were often the result of domestic disputes. About 30 percent of adult male victims were killed by wives or relatives, over half the adult female victims by husbands or relatives, and about three in every four victims under the age of 16 are put to death by their own parents or relatives. It is not surprising, therefore, to find that the majority of murderers are suffering either from severe mental strain or diagnosable
mental disorder: a third commit suicide before arrest; another third are found to be insane or of diminished responsibility (q.v) when brought to justice. Only the remaining third are sentenced as mentally normal, and some of these are later found to be disordered. Indeed, even murder by shooting is more typical of the mentally unstable offender than of the professional criminal, for out of sixty-nine murderers who used fire-arms in 1955-60, three-quarters elther committed suicide or were declared insane or of dinimished responsibility . . . Slightly over thirty murders a year were committed by men who were not diagnosed as mentally abnormal. In about $\mathbf{4 0}$ percent of these cases the cause seemed to be a quarrel or violent rage; in another 20 percent it was robbery or some other form of financial gain. In about 15 percent the motive was sexual. Rather more than half of these 'sane' male murderers had previous convictions, and of this majority more than half had previous convictions which were confined to offences against property; the others had convictions for violence or sexual crimes or both. Men in their twenties were markedly over-represented, whereas among suicidal and mentally abnormal murders there was a disproportionate number of older men [The same was true of women].

When it is realized that murders in Britain are so few-about four per million inhabitants every year-and that the sane murderer is responsible for less than third of them, it becomes clear how rare a person he is. His fatal act seldom seems to be premeditated. but more often to be the outcome elther of a sudden seems to be premeditated. but more often to be the outcome either of a sudden
quarrel or of a situation in which he is surprised or resisted in the course of committing a robbery or burglary. For every such case in which his victim dies there are many more in which he survives. In other words the typical sane murderer probably differs from other sane men who commit bodily violence only in one accidental respect-the fact that his victim dies.

72 Op. cit. supra, n. 5, at 258. 
course the neurotic delinquent is a representative of those neurotics who seek to punish their environment as well.

Common forms of neurosis of interest to the criminologist are: anxiety neurosis and phobias, obsessional and compulsive neurosis, and hysteria.

\section{(i) Anxiety Neurosis and Phobias}

This form of neurosis is one of the most frequently found in individuals. It is characterized by severe and chronic anxiety on the part of the individual about situations which would not call forth such a reaction in the non-sufferer. The ordinary degree of anxiety reaction present in all persons here reaches such an intense pitch as to markedly interfere with the sufferer's ability to cope with the demands of his environment. An example of the anxiety neurosis is presented by the student who requests permission to delay the writing of examinations when he has from an objective viewpoint prepared himself adequately for them.

When this intense anxiety is based upon an entirely unjustified perception of an object or situation it is usually termed a phobia.

The anxiety neurosis has little direct criminological significance although in severe cases it has been known to lead to suicide. In rare cases hospitalization may be necessary.

\section{(ii) Obsessional and Compulsive Neurosis}

The obsessional and compulsive neurosis is characterized by recurrent impulses or longings to perform irrational acts. This persistent longing towards irrational acts may give rise to perfectly harmless conduct such as stepping on every second crack in a sidewalk or, it may lead to acts of theft, arson, and exhibitionism. Recent English research ${ }^{73}$ has characterized the rare kleptomaniac as one who steals:

for the sake of stealing in a repetitive, compulsive manner. The act of touching and handling the goods gives ... sexual excitement, and it is often committed during or after menstruation or at the onset of the menopause. The thefts are carried out in a clumsy way, sometimes without any attempt at concealment; shining, glittering things are preferred, and they are often hoarded without ever being used.74

The similarity between the pyromaniac and the sexual offender has been noted in various research reports. It occurs most frequently in the younger age groups particularly among girls. The obsession which it represents seems to reflect a desire to destroy portions of the sufferer's environment which symbolize a corrupt world.

Deviant sexual desires may be reflected in compulsive behavior such as exhibitionism. The tensions created by efforts to repress the acting out of these desires may become intolerable and lead to relief by giving way to the compulsion. This relief is almost physical in its reality although it may often be followed by feelings of guilt and fear. The exhibitionist may travel continually through this cycle of compulsive desire, a building up of tension, relief through acting out, guilt and fear, and a renewed building up of the compulsive desire.

73 T.C.N. Glbbens, Theft from Department Stores, General Report to the Fourth International Criminological Congress, The Hague, 1960.

74 Op. cit. supra, n. 5 , at 261 . 


\section{(iii) Hysteria}

Hysteria may be described as "a condition in which the person has lost control over some sector of his behavior." "Th This may see the individual perform acts or utter words which are completely involuntary. The battle fatigue of an individual soldier so forcefully dealt with in the movie "For King and Country" provides a striking example.

The causes of hysteria are ultimately entirely emotional and the physical changes which may accompany it are completely reversible. The underlying basis of hysteria is always the same: it is the attempt, never fully conscious and frequently completely unconscious on the part of the sufferer, to obtain some advantage from the representation of symptoms of illness. These physical symptoms are as real as those based upon physiological causes alone. The advantage to the sufferer is the relief from insoluble mental conflict. Treatment must take this into account for, if it results in the destruction of the hysteria avenue of relief without providing an acceptable alternative, great harm may be done.

\section{(c) Maladjustment}

While mental illness accounts for a portion of anti-social behavior, the faulty development of personality cannot be overlooked in any survey of the aetiology of crime. There are those who attempt to explain all crimes on the basis of faulty personality development while others limit themselves to theorizing that the tendencies of individuals towards criminal behavior are the result of faulty development.

The former theories are sometimes referred to as "behavior specific" while the latter are thought of as "personality specific."

The behavior specific theories look to the form of the particular offence as being the most significant clue as to the nature of the personality of the individual offender. Thus criminal behavior may be seen as the reaction to an earlier traumatic childhood incident, or an attempt to attract parental attention and affection. The well-documented student difficulties of Winston Churchill could be explained by the apparent lack of attention shown to him by his ambitious and pre-occupied parents. The delinquencies may be an expression of desires which cannot otherwise be expressed, such as hostility towards a parent. Or, the offences may be an expression of an unconscious desire for punishment produced by guilt feelings arising out of acts such as masturbation.

These behavior specific theories seem to be most appropriate when explaining conduct which is clearly abnormal such as kleptomania and pyromania.

Theories of personality maladjustment which are considered personality specific relate to the individual's failure to develop a sufficiently strong ego and super-ego. Another personality specific theory as to the causes of inadequate personality development concerns itself with the concept of the "affectionless character."

If the ego is that part of mental life which controls the expression of instinctual drives and it is inadequate to do the task, the consequences for behavior patterns are obvious. Personality maladjustment character-

75 Op. cit. supra, n. 20, at 66 . 
ized by weak ego development may be the product of too permissive an upbringing or a congenital inability to develop an acceptable degree of self-control.

The inadequate development of the super-ego or an ingrained attitude which dictates as to the appropriateness of behavior is a personality specific explanation of anti-social behavior. It is this ingrained attitude which provides the ego with its terms of reference, or which directs the ego as to those instinctual drives which should be suppressed. A poorly developed super-ego leaves the ego without stimulus in the face of certain anti-social drives which when carried to fruition culminate in inappropriate behavior. The causes of an insufficiently developed superego have again been posited as the product of inadequate parental training or perhaps even a congenital inability to develop adequately along these lines.

A degree of maternal deprivation during the early years of childhood has been suggested as productive of an individual who having lacked the experience of affection early in life is unable to feel or express affection later in his own life. This lack of affection for others removes a common inhibition against delinquent behavior. In Bowlby's view this personality maladjustment is often expressed in acts of theft.

Turning to a more objectively based theory as to the causes of personality maladjustment, we must consider theories relating to the family.

That the family is an important factor in the development of the child's emotional, intellectual, moral, social, and physical potential has never been satisfactorily challenged. The child develops his ego strength within the family, and imbibes the raw material upon which his superego must function. The degree of development which a child achieves has a relation to the presence or absence of delinquency in his later years.

Unfortunately, the indiscriminate collection of a multitude of situations under the category of a "broken home" has done much to discredit the whole concept of the criminogenic influences of such a home. The lack of a precise meaning to the term has been commented upon by both Wooton and Mannheim. No striking contrast of the incidence of broken homes between delinquents and non-delinquents has been shown. ${ }^{76}$

Correlations have been observed between delinquency and marital discord, delinquency and female focused family organization, delinquency and inconsistent discipline within the family, delinquency and a boy's failure to win his father's affection, delinquency and a father's weakened influence within the family due to unemployment, and delinquency and the status of the family within the community. ${ }^{i 7}$ In the words of the U.S. President's Report of Crime:

Research findings ..., while far from conclusive, point to the principle that whatever in the organization of the family, the contacts among its member, or its relationships to the surrounding community diminishes the moral and emotional authority of the family in the life of the young person also increases the likelihood of delinquency. ${ }^{78}$

76 Glueck, Unraveling Juvenile Delinquency (1950) and Carr-Saunders, Mannheim, Rhodes, Young Offenders (1942).

77 Op. cit. supra, n. 3, at 63-65.

78..Id., at 69. 


\section{(d) The "Normal" Offender}

To some, the existence of a "normal" offender is a contradiction in terms. The offence itself is a symptom of abornormality. If normality is assumed to be the absence of psychosis, neurosis, psychopathy, or mental deficiency, the "normal" offender is then that offender whose personality contains none of these in its make-up.

One assumption is central to any discussion of the "normal" offender, and that is that there are psychological differences between offenders and non-offenders. The research has, however, been unable to isolate personality components unique to the offender group. In Wooton's view of the research, "personality traits are distributed in the criminal population in about the same way as in the general population." If If the conventional concept of normalcy is expanded to include the absence in the personality of ethical learning difficulties or a desire to obtain excitement by means of obviously legally forbidden conduct, the numbers of apparently "normal" offenders is diminished.

\section{(i) Ethical Learning}

Ethical learning is that process whereby the individual adopts guidelines which will govern his behavior. This form of learning is largely unrelated to other forms of learning such as intellectual, prudential, and perceptual. In infancy the individual is completely devoid of any ethical sentiments and they are only acquired during the course of maturing. This ethical learning process is perhaps another way of explaining the development of the super-ego.

The acquisition of this ethical learning appears to vary in magnitude among different individuals. The conditioning which it involves is a parental function which, of course, will be carried out in different ways by different parents. Further, the innate capacity of individuals to respond to this conditioning will vary.

It does not seem unreasonable to assume that a degree of failure of the ethical conditioning processes in an individual can account for his criminal behavior. If this is the case he can hardly be considered a "normal" offender.

\section{(ii) Excitement}

Criminal activity is usually thought of as being purposive, and not activity for activity's sake. There is, however, some evidence that teenage crime may be motivated to some extent by a desire for excitement. ${ }^{80}$ In the words of the U.S. President's Report on Crime, teenagers "engage with apparent abandon and indifference in whatever seems like fun, delinquent and non-delinquent."81 Again, to the extent that such excitement motivated conduct is noted as being more frequently a characteristic of the delinquent as opposed to the non-delinquent, he can hardly be considered a "normal" offender.

79 Barbara Wooton, Social Science and Social Pathology (1959).

80 Op. cit. supra, n. 20 , at 81 .

81 Op. cit. supra, n. 3 at 66. 


\section{(e) Psychopathy ${ }^{82}$}

In any study of abnormal mental life, account must be taken of a group whose mental disturbance is manifested not so much by their mental processes but by their behavior. From the criminologist's point of view this group represents those offenders whose conduct is typified by repeated collisions with the criminal law which appear to be the product of a marked incapacity to benefit from past experience. Repeated offences and punishments work no change in the pattern of their conduct and they only become more desperate and bitter. The psychopath begins his career in adolescence, it is usually life-long and appears to rest in part upon physical and emotional factors.

Physical characteristics of the psychopath which have been noted relate to the peculiar pattern of electrical activity in the brain as recorded by electroencephalograph, and immature formation of capillary loops in the nail bed. The mental functions expressed in the recorded electrical patterns of a significantly large number of psychopaths resemble those normally seen only in children.

The emotional immaturity of the psychopath is his most striking characteristic. In Stafford-Clark's words:

These people are impulsive, reckless, unwilling to accept the results of experience and unable to profit by them, sometimes prodigal of effort but utterly lacking in persistence, plausible but insincere, demanding but indifferent to appeals, dependable only in their constant unreliability, fruitful only to infidelity, rootless, unstable, rebellious, and unhappy..$^{83}$

This emotional immaturity of the psychopath is often demonstrated in his sexual life. This sexual life is frequently characterized by its opportunism, perversions, and shallowness.

A common classification of psychopaths is into aggressive and inadequate types. Walker has added a third-the callous type. ${ }^{84}$ The aggressive type is signified by his violence often following slight provocation. The inadequate type is as the name suggests incapable of managing even his petty crimes successfully. His employment record is spotty, and he is often found among the ranks of the confidence man. The callous psychopath forms no enduring human relations, and seems most notably lacking in conscience. The creative arts are occasionally represented in this group.

The prognosis of psychopathy is not an optimistic one. However, efforts are being made in England to combat, in a hospital setting, the tremendous waste of humanity which this affliction involves. The treatment program at the Henderson Hospital, Sutton, Surrey, takes into account that the most striking feature of the psychopath is his inability to profit from his experiences, and his disregard for the future. His insight into reality is imperfect and different from that of others. All his interpersonal relations lack duration, are never intimate, are insecure, and provide him with no work satisfaction. His sense of failure and dispair leads him into difficulty with authority. His anxiety and guilt feelings are so great that he cannot face them, and instead he acts them out. He has an overwhelming need for punishment and in this respect

82 Following the discussion. in: David Stafford-Clark, Psychiatry Today (1952).

83 Id., at 117.

84 Op. cit. supra, n. 20 , at 83. 
the present Canadian penal system provides him with that needed item. The Henderson program recognizes that the psychopath cannot be treated by deterring acting out but instead he must learn to understand the reasons for his acting out.

The treatment of the psychopath at Henderson is by way of community therapy which involves the whole staff-patient group in a program designed to make the individual aware of his own problems, and those of others in the community. Feelings are openly shared and discussed. Projection by the patient of unacceptable parts of himself is not tolerated, and the need to do this is diminished by the community's attitude of understanding and acceptance. A frankly permissive atmosphere is cultivated at the Hospital. ${ }^{85}$ Every possible measure is taken to involve the patients in the administration and treatment program. In the words of F. N. Taylor:

No attempt is made to deny that the patients are sick but they are encouraged to develop a capacity for responsibility; responsibility to seek the answer to the problem of their personal relationships, responsibility to help others to do the same, responsibility to make the community function as smoothly as possible in all its aspects. 80

The community pressure to accept this responsibility is strong. Again referring to Taylor:

The staff aim is to help the patients to participate and express their feelings and ideas in the various group discussions. Private communications are discouraged and each patient is expected to look to his group or to the total community for support and to help him in working out his problems. . . . Acting out has to be tolerated and must never be condemned. The patient has to be encouraged to become aware of the real relationship difficulties which are responsible for his acting out and gradually to learn to establish his own controls. It is on the ability of the staff to handle the unconscious defences against despair that the success or not of therapy depends. ${ }^{87}$

The results of the Henderson community therapy have been evaluated by two independent studies. Rappoport found 41 per cent of the patients improved and 31 per cent failures a year after discharge. Tuxford found 24 per cent very good, 31 per cent improved and 45 per cent poor or a complete failure.

\section{(f) Mental Deficiency}

A New York study of 10,000 consecutive felons revealed that 2.6 percent could be classed as mentally deficient. The relationship between intelligence and delinquency has been a subject of speculation since the research of Alfred Binet in France in the nineteenth Century. The early view of crime as a rational choice of conduct led to the doctrine that mental defectives in common with infants and the insane were not legally responsible for their actions. Mental deficiency was differentiated from insanity in the early nineteenth century but it was not until late in that century that scientific standards were established for the measurement of degrees of mental ability.

In any consideration of the relationship between intelligence and delinquency it must be borne in mind that those factors contributing to a resultant IQ score may also contribute to delinquency. Comparisons

85 The writer, having spent several days at Henderson, can attest to some of the consequences which this atmosphere has in terms of insights into the nature of various patients who have been labelled psychopatic.

86 The Treatment of Delinquent Psychopaths, (1963), II The Howard Journal 87.

87 Id., at 89 . 
between the intelligence of delinquents and non-delinquents should not admit any variable other than delinquency if they are to be useful. It may be that inferior mentality is becoming one of the attributes of those individuals selected by society for the delinquent group although Walker ${ }^{88}$ denies this to be the case.

According to Schulman, ${ }^{89}$ one attritube of the mentally deficient is that they come from the lower socio-economic groups. ${ }^{90}$ As one progresses along the line from court to penal institution the intelligence level drops. Goring indicated an association between forgery and fraud and higher intelligence. Crimes of violence he associated with lower intelligence levels. In Abrahamsen's view the offence committed is typical of the individual's intelligence.

Extreme mental defects may be attributable to grossly perverted infant rearing in about 10 percent of all cases. For many years attention has been devoted to psychological injury in early life as a cause of mental disorder, but the same possibility has been almost ignored in severe mental deficiency because this is usually associated with obvious organic disease. There is a strong possibility that emotionally unfavorable environments are a significant cause of mental deficiency. ${ }^{01}$

Congenital intellectual deficiency describes those who from birth show evidence of inferior intellectual capacity or ability. This intellectual deficiency has been defined as a state of restricted potentiality for, or arrest of, cerebral development in consequence of which the person affected is incapable at maturity of so adapting himself to his environment or to the requirements of the community in order to maintain an existence independent of external support. ${ }^{92}$ Intellectual deficiency may arise from environmental or hereditary factors, intra-uterine disorders of development, or early childhood injuries to the nervous system by infection or trauma. Intelligence is measured by such tests as the Stanford-Binet test and the Wechsler-Bellevue test. It is important to remember that the results of these tests may be affected by factors other than the innate intelligence of the subject. The Binet test gives a score in mental age which, when divided by chronological age, gives the Intelligence Quotient or I.Q. These are classes of intellectual capacity-the idiot with an IQ of less than 25; the imbecile 25-50; the moron 50-70; the borderline deficient 70-80; the dull normal 80-90; the average $90-110$; the superior $110-120$; the very superior, above 120; and the genius or near genius, 140 and above. Any diagnosis of intellectual capacity should be based upon clinical judgment as well as psychological testing.

The energy level of the intellectually deficient is not high, and as a consequence they are not usually aggressively anti-social. However, they are easily led, and having little foresight of consequences may well find themselves in trouble with the criminal law.

The chief defence against intellectual deficiency is prevention by

88 Op. cit. supra, n. 20 , at 59.

$89 \mathrm{H}$. M. Schulman, "Intelligence and Delinquency," [1950-51] Journal of Criminal Law, Criminology and Police Science, 763-781.

90 In a report prepared by the Edmonton. Welfare Council it is estimated that there are 43,680 mentally retarded persons in the province, with 8,736 of them being under are 43,680 mentally retarded persons in the province, with 8 inotionally Disturbed and the age of 20: (1967) An Examination of Fat

91 Retarded Children in the Province of Alberta, 5 . (1965) 11 The Lancet, 1156-1163.

02 Guttmacher and Weihofen, Psychiatry and the Law 172 (New York 1952 ). 
means of sterilization..$^{93}$ According to Dr. Elliot Slater intelligence is determined by the presence or absence of a very large number of genes of both positive and negative effect. Where many genes of positive effect are present, intelligence will be high; where a majority of genes present are of a negative effect, intelligence will be low. An overall decline in the intelligence of the general population may result from the decline in the number of children produced by couples of above average intelligence.

To effectively deal with the problem of intellectual deficiency, sterilization must be carried out over a period of many generations. This sterilization program may be based upon both hereditary and environmental considerations.

\section{(g) Psychiatry and the Courts}

The following statement by Guttmacher and Weihofen ${ }^{04}$ is probably as concise a statement relating law and science as can be found:

The administration of justice is a social and political function, which has to serve other objectives besides that of probing for truth. Scientists may have to work for decades and even for centuries to find an answer to a problem, and the fact that time is passing is not accepted is an excuse for hasty and inadequately tested conclusions. But social and political problems must be answered as they arise. Disputes have to be settled and rights clarified, and it is sometimes necessary to accept something less than wholly accurate results in order to get reasonably speedy results, for justice delayed is often justice denied. One of the chief functions of the law is affording the individual security, by the prompt resolution of personal and community tension.

The medical witness in the adversary system of trial is placed in a disadvantageous position because of the difference in the philosophies of the law and medicine as expressed by the nature of the requisite training of its respective practitioners. Legal training stresses skill in generalization while medical training cautions against the scientific hazards of generalization. The law focuses primarily on society while psychiatry focuses on the individual. Free will is the cornerstone of the criminal law while psychiatry leans towards the philosophy of determinism.

In a criminal trial issues are settled on the basis of persuasive power, and not on the basis of objective truth. In allowing expert testimony the basic question which the judge must decide is whether or not the testimony of the proposed witness will help the court in determining the issues.

The effective use of the expert medical witness is subject to a number of general observations. The extent of his special knowledge should be fully presented to the court. He should always state the facts upon which his opinion is based, and the process of reasoning from these facts to his concluding opinion should be made apparent. Of course, the witness should not lecture or argue and this must be pointed out to him prior to his being called as a witness. Where the insanity of the defendant is in issue, the medical witness should not be prevented from stating his opinion as to the defendant's knowledge of right and wrong, but he should not be required to do so for these concepts are far remote from the field of his expertise. It is essential that both the lawyer and the medical witness should understand both the medical and legal issues involved in

98 See the Sexual Sterilization Act, R.S.A. 1955, c. 311

94 Op. cit. supra, n. 92, at 206. 
the case. For instance, the medical witness should understand the nature of the hearsay rule which will forbid him from expressing an opinion based in whole or in part on information coming to him from others. Thus, case histories are often excluded from evidence, and as a result a full presentation of the medical history of a defendant is hindered.

Evidentiary rules may allow the opinions of an expert witness who may never have seen the patient to be introduced by way of the hypothetical question. ${ }^{95}$ However, a difficulty arises in determining how much of the evidence should be included in such a question. This determination should be made in the absence of the jury and the witnesses.

Suggestions have been made from time to time that the partisan nature of the expert medical witness could be eliminated by the use of impartial medical examiners. The Baltimore Psychiatric Court Clinic has adopted this practice and in this way has done away with the battle of experts.

The veracity of court testimony could in a large measure be evaluated by scientific techniques not presently allowed by the conventional rules of evidence ${ }^{\theta 6}$. It is well known that the advocate's art relies to a large measure upon extracting from a witness "suitable" answers to questions. Clarification of these resulting distortions depends upon the perceptiveness and skill of the advocate for the other side. Seldom are these two features of a case evenly balanced.

Fundamentally, there are two types of lies-defensive and pathological. Defensive lying is a common feature of most personalities.

A good deal of what is regarded as "lying" on the part of the accused may be actually a negativism born out of deep fear. Often people "lie" against their own inner interests. "Lying" is often a defence against inner feelings of insecurity and inferiority. The insane do not lie-they expose the truth with alarming candor. This leads us to a paradox that mental integrity may rest on the capacity for denial, for sustained repression of the truth. ${ }^{97}$

Wigmore has suggested that no judge should ever let a sex charge go to the jury unless the female complainant's social history and mental makeup have been examined and testified to by a qualified physician. Pathological lying on the other hand is a personality trait which will last a lifetime and is disproportionate to any discernible end in view.

In the criminal law problems of veracity are closely related to confessions. It is ego strength which largely determines an individual's ability to withstand pressures to confess. Confession may reduce inner tensions for the individual, and this may account for spontaneous criminal confessions. Some mentally abnormal individuals will give false confessions which they frequently retract at a later time.

The concept of crime comprises the concurrence of a prohibited act and a wrongful intent. If this wrongful intent is absent no act, however stern the law's prohibition, is a crime. The nature of the necessary intent varies from crime to crime. "Once it is determined that a man intended to do the act, the inquiry is at an end; the law is not interested in why he meant to do it." ${ }^{98}$ Modern knowledge in the behavioral sciences

95 Bleta v. The Queen, [1965] 1 C.C.C. 1, 48 D.L.R. (2d) 139, [1964] S.C.R.

96 The recent use of hypnosis in court in British Columbia in the Pitts case may be a portent of things to come.

97 Op. cit. supra, n. 92, at 375

88 Id, at 402 . 
demonstrates, however, that criminal conduct is the product in part of many complex mental forces. No single mental process such as the cognitive mental process is solely responsible. Conscious and unconscious motivations hold the key to an understanding of human conduct. The criminal law notion that motives are irrelevant must be abandoned.

The isolation of non-deterable offenders on the basis of their sanity or lack of it in Canada is done by making use of the M'Naghten test of insanity as that test is stated in a form slightly altered from the original in s. 16 of the Criminal Code. The test enunciated in the section is entirely a cognitive one designed to determine (1) whether the accused appreciated the nature and quality of the act, and (2) whether he knew the act to be wrong. The nature of these questions is far from clear and particularly doubtful is the meaning of "wrong." Modern psychiatric knowledge indicates that this test fails in many instances to isolate the non-deterrable offender. The American Law Institute's Model Penal Code, Section 4.01 adopted in U.S. v. Freeman ${ }^{30}$ provides a more responsive test:

(1) A person is not responsible for criminal conduct if at the time of such conduct as a result of mental disease or defect he lacks substantial capacity either to appreciate the wrongfulness of his conduct or to conform his conduct to the requirements of law.

(2) The terms "mental disease or defect" do not include an abnormality manifested only by repeated criminal or otherwise anti-social conduct.

The Canadian law's position in regard to the mental element in crime has remained unchanged for many decades; however, noticeable changes have been made in regard to present insanity as a ground for postponing criminal proceedings. ${ }^{100}$ The revision of the test for insanity has proved almost impossible. Therefore, the means of postponing the trials of seriously intellectually defective or mentally disordered defendants have proved to be of major importance in escaping from the rigidities of $s .16$.

\section{Some Sociological Factors in Crime}

It is the concern of criminal sociology to observe the nature of the relationships of the individual to his society wherever and whenever these relationships might reasonably be thought to contribute to criminal behavior. Implicit in this notion is the assumption that there are forces in society which may be productive of criminal behavior. Of course, individual and collective bias will have a part to play in determining what forces will be assumed for the purposes of research to be criminogenic forces.

If crime is to be considered an integral part of a culture as Durkheim did, it is necessary to define culture in terms that will allow the relative position of crime to be observed. For this purpose culture may be thought of as the sum-total of the arrangements which men have made for themselves within which their lives are to be lived. The creation of these living arrangements involves the acceptance or rejection of various patterns with crime being a rejected pattern in any but an isolated sub-culture, but it remains a part of the social scene. This rejection of the criminal pattern by a culture is a positive act, and we thus can

\footnotetext{
99 (1966) 357 Fed. R. 2d 606

100 Examples of this development are found in ss. $451(\mathrm{c})$ and 524 of the Criminal Code of Canada, supra, n. 36 .
} 
say that every culture creates for itself its own particular kind of crime and criminals.

The observation is commonly made that, while Western societies have achieved increasingly widely distributed affluence, crime has also increased. What are the fundamental forces behind this malaise? The questioning of widely held aspirations which this would involve could lead to a questioning of the relative merits of the aspirations themselves. No doubt, this would lead to the rejections of some as unworthy. Perhaps the disturbance of the living arrangements which would follow are instinctively felt to be too cataclysmic to be risked. Consequently, the search for criminogenic forces seldom attempts to penetrate into the core aspirations of a culture. Instead the search concentrates only upon the manifestations of those core aspirations. This concern of the criminologist with peripheral forces is in part a reflection of widely held attitudes and, in part, the result of a lack of adequate research tools.

Western societies have for centuries accepted certain objectives as worthy of individual aspiration and the contemporary criminologist finds it exceedingly difficult or unpopular to conduct his work in a manner which casts doubt upon the worthiness of those aspirations. Thus, the dearth of fundamental thought in criminal sociology upon central issues. The characteristic thrust has instead found expression in forms compatible with the prejudices and values of an increasingly enervated public.

The aspirations of this public which is, among other things, genuinely disturbed about the rising rate and magnitude of criminal behavior are increasingly shaped by a diminishing concern with the quality of individual life and an increase in the belief that "more is better." This quantitative approach to the life processes of a culture places many obstacles in the way of the development of individual powers of discretion by obscuring the non-quantitative factors which add or detract from the richness of individual or collective life. The modern community's preoccupation with the state of its economy is an example of this quantitative view which masks much of significance.

It is inevitable that such a collective concentration upon economic factors will have an abrasive effect upon those who view them. The viewer begins bit by bit to apply economic criteria of good and bad to the formulation of aspirations. The pre-eminent economic criteria of good or bad is measured in terms of the acquisition of units of economic value-hence more is better.

The distortion of individual and critical faculties which this abrasive process has brought about is central to any understanding of the alleged paradox of increasing amounts of crime in the midst of relative affluence. The creation of a mean economic philosophy as the dominant fabricator of the living patterns of a culture must be mirrored in an extraordinary concern with material things, and it is material goods which are the objective of the vast majority of all criminal acts as the briefest perusal of Canada's criminal statistics will show.

It is certainly not the business of the criminologist to evaluate the relative merits of the living patterns of a particular culture. However, he should be concerned to discover what effect those patterns have in 
provoking conduct which the culture has rejected as undesirable. To do this, thought must ultimately be directed towards such matters as a modern society's apparent ability to destroy its capacity to choose, from among competing aspirations, those which will add to the quality of the culture and those which will not.

Turning to past attempts to explain criminality in social terms we find their outstanding characteristic to be an insistence that the cause of criminal behavior lies not within the individual, but outside.

\section{CRIME AND SOCIAL CLASS}

While the word "class" is of common usage, its exact meaning is yet to be fixed with any precision. The general assumption of long standing in the literature on the subject is that Western Society may be broken into three classes: upper, middle; and lower. Some of the criteria which aid in assigning an individual to one of these classes or the subdivisions which have in later times been created are wealth, education, occupation, speech and accent, family background, housing, child rearing habits, level of aspirations, interest in serious arts, literature, and cultural pursuits. ${ }^{101}$ The individual's subjective view as to the class he belongs to may also be a determining factor.

The whole question of class structure is of concern to the criminologist from the point of view of determining the effect of class upon patterns of crime. How does conflict between classes or mobility between them effect criminal activity in the community? That such conflict exists between classes cannot be denied, but its intensity and consequences are not well known. We do know, however, that Marx's polarization of class conflict has not been maintained, and that classes have proliferated, and not been reduced as he prophesied.

Mobility between classes is an article of faith in Western society. But English research into the subject indicates "there is less upper mobility than one might have expected, and downward mobility is far from negligible."102 While imitation by the members of a lower class of the practices of a higher class reduces conflict, and indicates attempts at upward mobility, the rebel must surely be indicative of the rejection of the right of any particular class to dominate.

The influence of social class upon the incidence of crime has been commented upon frequently by persons interested in the subject. In Mannheim's words:

The history of criminal legislation, in England and in many other countries, shows that excessive prominence was given by the law to the protection of property against comparatively minor depredations which of course means that the types of offences likely to be committed by members of the lower social classes figure more predominantly than others in criminal statutes and therefore, also in the criminal courts and criminal statistics. On the other hand there was a marked reluctance to treat the various forms of fraud as criminal offences. . . . It is only in comparatively recent times that those forms of antisocial behavior more congenial to the position, ways of life, and mentality of the higher social classes have been seriously considered for inclusion in the penal codes and statutes. ${ }^{108}$

Both English, ${ }^{104}$ and American ${ }^{105}$ studies have concluded that delin-

101 Mannheim, Op. cit. supra, n. 5, at 446.

102 Wooton (Dec., 1954), 5 Brit. J. Sociol. 371.

103 Op. cit. supra, n. 5 , at 460 .

103 Morris, op. cit. supra, n. 4.

106 Cohen, Delinquent Boys (1965). 
quency is a social characteristic of the lower classes. It is perhaps fair to say that the misdeeds of University students are dealt with in a fardifferent way than those of the young manual laborers.

(a) Distribution of Offenders by Class

Using a recent English census estimate of the social classes in England, Morris ${ }^{106}$ shows the distribution of Probation and Approved School cases as follows:

$\begin{array}{lr}\text { Class III-1 case per } & 3,003 \\ \text { Class IV-1 case per } & 380 \\ \text { Class V-1 case per } & 187\end{array}$

He also sets out data produced by Warner and Lunt covering arrest rates over a 7-year period in an American city ${ }^{107}$ (see Table III).

\begin{tabular}{lcc} 
Class & \% of Population & \% of Arrests \\
\hline Upper & 1.44 & 0.43 \\
Lower-Upper & 1.56 & 0.28 \\
Upper-Middle & 10.22 & 1.84 \\
Lower-Middle & 28.12 & 7.80 \\
Upper-Lower & 32.60 & 24.96 \\
Lower-Lower & 25.22 & 64.69 \\
\hline
\end{tabular}

Table III: Distribution of the Commission of Crime Among Social Classes

If educational level and nature of employment are meaningful criteria of social class, Table IV relating to the U.S. prison population and based upon the 1960 U.S. Census of Population is revealing. ${ }^{108}$

\begin{tabular}{lcc} 
& Prison Population & General Population \\
\hline Median years of School completed & 8.6 years & 10.6 years \\
Percentage employed as Laborers & $23.9 \%$ & $5.1 \%$ \\
$\begin{array}{l}\text { Percentage in high status occupations } \\
\text { (Professional, Technical Manager, }\end{array}$ & $5.8 \%$ & $26.6 \%$ \\
$\quad$ Official, Proprietor) & & \\
\hline
\end{tabular}

Table IV: Comparison of Educational Level and Type of Employment of Prisoners With the General Population.

The class distribution of offenders should be readily apparent. What is not so apparent are the causes of this difference in rates of crime between classes of their rates of arrest and imprisonment.

\section{(b) Distribution of Offences by Class}

An indication of the class distribution of offences can perhaps be found in the Canadian game laws which, while serving the ends of conservation-a middle class value, may have a marked tendency to penalize a common pastime of the rural and lower classes. Thus, the description often given to game laws of "mischievous class legislation."

For some categories of offences some evidence is available as to their distribution by classes. These offences are: sex offences, art forgeries and embezzlement, abortion, shoplifting, and motoring offences.

\section{(i) Sex Offences}

The Cambridge survey ${ }^{109}$ found that skilled and unskilled laborers predominated among all hetro-sexual offenders. On the other hand the

\footnotetext{
106 Op. cit. supra, n. 4, at 166

107 Id. Table 22 at 166.

108 Op. cit. supra, n. 3, at 45.

109 Sexual Offenders, 9 Cambridge Studies in Criminology (1957).
} 
survey found that the classes above that of laborer were markedly under represented. The large sample of offenders used by the survey $(2,000)$ found that sex offenders in the sample tended to have a higher general level of education than the general male population, particularly in the case of the homosexual offenders. The hetro-sexual offender and the exhibitionist on the other hand appeared to have a lower general level of education than the general male population. A preponderance of higher occupations was noted among the homosexuals. Another study ${ }^{110}$ of men convicted of sexual offences against children indicated that the homosexuals from higher social levels predominated. The manner in which the various sexual offences are dealt with seems to depend in some measure upon the social classes of those persons involved in the offence. ${ }^{111}$

\section{(ii) Art Forgeries and Embezzlement}

These offences are of a nature which demands a certain kind of opportunity which can only be provided by a higher than usual level of education, certain cultural attainments, and the confidence of others. Thus, the marked predominance of the middle classes in these offences. The success of the art forger depends in part upon the existence of the foregoing conditions, and upon the class attitudes of his victims. In Mannheim's words: ${ }^{112}$

The modern multi-millionaire, partly to impress his friends and competitors, partly to find a 'safe' investment for his fortune or to re-sell with great profit or to buy a title, spends enormous sums on genuine or faked works of art either to keep them in his own home or to present them to a museum (for which he can, at least in the United States, obtain some considerable tax benefits). The ingenious manner in which the snobbery or greed of such men has been exploited by highly skilled forgers is common knowledge.

The predominance of the middle-class among embezzlers has often been commented upon. The bank employee and the lawyer occupy this field almost exclusively. The nature of their work and the great measure of trust placed in them by multitudes of persons presents exceptional opportunities for offences of the kind contemplated by ss. 276 and 278 of the Canadian Criminal Code-theft by persons required to account. Opportunities for offences of this kind are very restricted in the case of the lower classes. ${ }^{113}$

The relative infrequency of prosecution in cases of art forgery and embezzlement is perhaps found in the victim's reluctance to expose his errors of judgment, the social links between the offender and the victim, and the offender presenting no serious threat to community values. ${ }^{114}$

\section{(iii) Abortion}

The representation of a professional class here is of course high, and this is inevitable when the medical skills of the doctors are so essential for the proper performance of the offence. No doubt a substantial number of abortions are performed by unskilled persons but here as well it may

\footnotetext{
110 Fitch, 3 British Journal of Criminology, 18-37.

111 Op. cit. supra, n. 5, at 463.

112 Id., at 464 .

113 Martin's Offenders as Employees (1962, MacMillan), is a useful study of the lower class "embezzlement" which takes the form of petty theft most frequently. $11 \div$ Op. cit. supra, n. 5 , at 465 .
} 
be reasonably assumed that these persons are chiefly from the middle classes.

The distribution of social classes among the "victims" may well be slanted towards an under-representation of the lower classes due to the economics of the offence. Certainly the trend would be accentuated by legislation which falls short of removing the subject entirely from legislative meddling.

\section{(iv) Shoplifting}

The absence of any conclusive research findings in regard to the class distribution of this offence leaves the matter at present open to speculation. In an acquisitive society it would seem reasonable to assume that any social class which has a strong impulse to acquire and to which at the same time is denied approved means of acquisition will be overrepresented among shoplifters.

\section{(vi) Automobile Offences}

These offences constitute the largest single type of offence, yet are thought of by many not to count as crimes at all.115 While the possession and operation of an automobile was initially the prerogative of the relatively well-to-do, the technology of Detroit has not only destroyed the original class distribution of automobile offences, it has also contributed to the blurring of class lines of demarcation themselves.

Willett's ${ }^{110}$ study of the subject revealed that the lower classes were over-represented in his sample of automobile offenders. The type of offence indicated some peculiarities in the class distribution of offenders. Driving while uninsured or without a valid license was the forte of the manual worker. Driving under the influence of alcohol appeared to be the most noticeable offence of the non-manual worker. Only a minority of Willett's sample of offenders considered the offence as being one of a truly criminal nature. Of particular interest was his finding that the police and the courts treated the motoring offender in a much different way than other offenders. This differential treatment has in fact received legislative sanction in some jurisdictions with the creation of categories of motoring offences which may be disposed of by the payment of a pecuniary penalty without the usual court appearance.

\section{SOCIAL CONFLICT}

There is in existence a considerable body of opinion which theorizes that crime is not the result of breaking some generally accepted norm but is instead the result of a conflict between different value systems held by different groups. One group being dominant it makes use of the criminal law as an engine to enforce its value system upon all the other groups.

If there is evidence of a "rough working class"117 in existence whose values and behavior are markedly different from the values and behavior generally subscribed to in the community, and if these values and forms of behavior are short-term and hedonistic, perhaps we have some ev-

115 Op. cit. supra, n. 76, at 26.

116 Willett, Criminal on the Road (1964).

117 Grygler, Jones, Spencer, Criminology in Transition 12 (1965) 
idence upon which a social conflict theory of criminal behavior can be based.

There is an implicit assumption by the holders of current middle class values that they are superior to those of the rough working class, but:

a comparison of our way of life [middle class] with theirs may very well lead us to conclude that we have no right to assume that our own practices are superior in themselves to theirs. There is no necessary virtue in self-denial, and when it is carried to the extreme lengths that it is in highly ambitious or very conscience-ridden groups, it becomes merely self-punishing. It may sometimes be very effective as a mean to advancement, but this is an argument from expedience, not ethics; and if (as is so often the case) the same motives drive the individual throughout his life, so that he never reaches the point at which gratification seems right to him, then one may even question its practical value. ${ }^{118}$

This striving and self-denial practiced by the middle classes may be perceived by the rougher group as ridiculous and, in the face of the self-justificatory assertions made by this upper group, provocative, leading to a deliberate emphasis by the rougher group of their own value systems and forms of behavior. Both groups begin to blind themselves to the merits and demerits of their particular systems. The lower groups in emphasizing its behavior patterns naturally is very near or over the line which divides criminal behavior from the non-criminal. Their ready resort to violence, intolerance of frustration, and direct approaches to goal achievement makes this so. These attitudes are also displayed in their child-rearing practices, and thus we see the transmission of cultural patterns.

Little is gained by denying the split in our society. Rather we should accept the differentiations found between classes and upon this basis extract what we can of value discarding the hypotheses thus made possible when they no longer serve any useful purpose. If we act upon this basis we can observe more than one social class in Canada, each with its own distinct set of ethics overlapping in some respects and diverging in others. ${ }^{110}$ What makes this divergence significant is the relative dominance of one group by the other. This dominant group has greater control over the legislative processes and is in this way able to give expression to its distaste of behavior patterns diverging from its own.

\section{WHITE-COLLAR CRIME}

The classic definition of white-collar crime has been provided by Sutherland when he described it as crime "committed by a person of respectability and high social status in the course of his occupation."120 Most crimes are accepted by the public as appropriate, however, there is endless controversy as to whether or not conduct which conforms to Sutherland's formulation ought or ought not be labelled criminal.

Sutherland's research into the subject was concerned "with violations by businessmen and corporations of laws covering restraint of trade, misrepresentation in advertising, infringement of patents, unfair labor practices, and financial manipulations such as violations of trust and public

\footnotetext{
118 Id., at 13.

119 For an empirical examination of social classes in Canada see: Porter, The Vertical Mosaic, An Analysis of Social Class and Power in Canada (1965). Of particular interest to lawyers is the note at $415-416$ on the senior judiclary.
}

120 Spencer, White-Collar Crime in Op. cit. supra, n. 117, at 233 . 
misrepresentations." ${ }_{121}$ By examination of the decisions of the courts and regulatory commissions applying to 70 of America's largest corporations over approximately 45 years of their history he found that 980 decisions had been registered against the corporations with each corporation having at least one decision rendered against it. 98 per cent of the corporations had 2 or more of these decisions rendered against them. 90 per cent had 4 or more decisions adverse to their conduct. 60 per cent of the corporations had been convicted in the criminal courts with the average number of criminal ocnvictions being 4. In the words of a recent American Report: ${ }^{122}$

Corporate and Business-"white-collar"-crime is closely associated with the widespread notion that, when making money is involved, anything goes.

There is no doubt that white-collar crime is a subject "about which the criminal justice system, and the community as a whole, have little knowledge." ${ }_{233}$ In the U.S. costs of Fraud, Embezzlement, and Tax Fraud are estimated at $\$ 1,650$ millions annually. The New York Salad Oil Fraud has been estimated as involving losses of \$125-175 millions. ${ }^{124}$ In Canada, the costs of fraudulent bankruptcies in recent years have never been authoritavely estimated.

What are the costs to society of this form of activity? It can result in injury or death when Food and Drug regulations are not observed. The financial loss covered by the sale of defective goods or false advertising are doubtlessly enormous. ${ }^{125}$ Most significant among the costs of whitecollar crime is the general deterioration which it produces in the social, economic, and political life of a nation. These costs cannot be measured in any conventional terms.

The traditional concern of the criminal law has been with conventional forms of behavior found predominantly in the lower classes. This approach hides the seriousness of white-collar crime, and in particular the importance of power in defining crimes and the social forces which cause it.

No behavior which is not anti-social should be considered criminal, but not all anti-social behavior should be made criminal. The absence of complete concurrence between anti-social behavior and criminal behavior can be explained by:

1. The low visibility of some forms of anti-social behavior which masks this behavior from the legislator.

2. Different social classes have different views as to what ought to be considered as criminal.

3. The technical difficulties are too great in making certain forms of anti-social behavior criminal, for example, false advertising.

4. The making of some forms of anti-social behavior criminal involves what is considered to be too great an interference with individual freedom of action. ${ }^{20}$

121 Id., at 235.

122 Op. ctt. supra, n. 3, at 17.

128 Id., at 5 .

124 Id., at 33 .

125 Section 306 of the Criminal Code of Canada, supra, n. 36 attempts to deal with false advertising but Canadian Criminal Statistics do not record the number of offences under the section coming to the attention of the police or prosecuted. This section is slated to become s. $33 \mathrm{~B}$ of the Combines Investigation Act.

120 Op. cit. supra, n. 129, at 284. 
Thus, it can be seen that there are great difficulties in defining certain forms of behavior as criminal. It would seem, however, that as society moves towards even more complex and better understood human interactions the greater will become the concurrence between that which is anti-social, and that which is criminal. This assumes of course that reliance continues to be placed to the same extent as at present upon the penal sanction as a method of social control.

Considering white-collar crime as "normal," at least in the eyes of those engaged in it, Clinard's study of the American Black Market during World War II, based on the records of the Office of Price Administration (OPA), is an important work when considering why criminal sanctions are either not applicable or not enforced. He took the position that if behavior was legally forbidden that behavior was white-collar crime. A formal criminal sanction was not necessary for such behavior to be considered sociologically a crime. Clinard showed that in a total of 259,966 sanctions applied during the five year existence of OPA, only 13,993 criminal prosecutions were involved. Only about 25 per cent of those criminally convicted were imprisoned and then only for relatively short periods. The courts were extremely reluctant to label the conduct of businessmen as criminal.

Clinard put forth four main reasons to explain their differential treatment of the businessman. (1) The doctrine of caveat emptor. (2) The status of the offenders. (3) Difficulty in detecting the behavior. (4) The difficulties involved in the prosecution of corporate offenders. ${ }^{127}$

As Clinard's research has made apparent, definitional difficulties need not lead to the predominance of legal definitions in criminological research. Criminal law data is useful to the researcher but he must be free to make use of other classifications independent of those of the criminal law.

The absence of agreement as to the values to be enforced by the criminal law is typified by the nature of the efforts made to control whitecollar crime. This, of course, poses a very fundamental question in our society. Should the criminal law be used to protect against property as well as to protect property? Its use for the latter purpose is well known. What is less clearly understood is the use of property to thwart the achievement of the democratic ideal. ${ }^{128}$

The relationship between business practices and white-collar crime is close with the regulation of business practices being left for all intents and purposes in the hands of the business community. In Durkheim's view, ${ }^{129}$ this meant that no effective internally imposed regulation is possible given the isolation of the individual businessman in a hostile and profit motivated environment. The ineffectiveness of regulation of business practices when left to the commercial world is best shown in Canada by the absence of effective control over advertising and security promotion and sales. Given the relative absence of externally imposed controls this is perhaps to be expected. A peculiar manifestation of the relative lack of externally imposed controls over business practices has

127 See: R. v. J.J. Beamish Construction Co. Ltd. et al (1967), 1 C.C.C. 301 (Ont. H.C.) for an example of the consequence to a criminal prosecution of a corporate merger in Ontario.

128 See Deutscher, The Unfinished Revolution 106 (1967).

129 Durkheim, The Division of Labour in Society (1933). 
been mentioned by Professor Gower ${ }^{130}$ when he points out that the increasing volume of social legislation has had little impact on Company Law.

Canadian experience with gaining protection from the power of property has proved one thing in Spencer's ${ }^{131}$ opinion: that the Criminal Law's power to do this is ineffective. In Canada the Combines Investigation $\mathrm{Act}^{131 a}$ is the main weapon available against monopolistic practices. Under this Act the Director of Investigations and Research is charged with the responsibility for investigating suspected violations of the Act. If there is prima facie evidence of a violation as determined by the Restrictive Practices Commission, a report is sent to the minister responsible for the administration of the Act who must then decide if a prosecution is justified. Prosecutions are also possible under S. 409 of the Criminal Code.

It is the intent of both the Combines Investigation Act, and S. 409 of the Code to maintain competition amongst business enterprises. The assumed competence of the market place to regulate economic activity in socially acceptable directions which.this legislation assumes is nothing short of disaster. To quote Professor John Galbraith: ${ }^{132}$

The most painful consequences from assuming the competence of the market are in urban and suburban housing, commercial and other real property development. . . The proper instrument for urban and related land acquisition and administration is a strong planning, housing and development authority. And, no less than for the manufacture of automobiles or the colonization of the moon, it will require the scale, financial autonomy, control over prices, and opportunity to develop a technostructure which are the requisites of effective planning. (Italics mine.)

According to Professor Galbraith as firms become larger the dividing line between private business and government becomes even more indistinct. Perhaps it is an unconscious awareness of this fact that has produced such inadequate results from the administration of the legislation in question. Up to 1964 there were a total of 22 convictions out of 29 prosecutions. ${ }^{133}$ These convictions were for activities in the form of fraudulent tenders, pricing practices, or practices intended to eliminate smaller competitors.

This maintenance of a posture of support for a traditional economic system is a good example of a failure to recognize changes in social reality. There is great danger then in an over-reliance upon the engine of penal legislation as a device for social control, for the penal law will find itself acting against forces which are of too great a magnitude for it to contain successfully, just as the Combines legislation is unable to stem with traditional market theories the march of new economic practices. Certainly Canadian legislative efforts to protect the public against the power of property have not been successful and have only succeeded in expanding the number of white-collar business "criminals" who are reacting to social and economic forces in the only way they know given their acceptance of the Hobbesan notion of every man against every other man.

\footnotetext{
130 Gower, Business in Ginsberg, Law and Opinion in England in the Sixth Century (1959).

131 Op. cit. supra, n. 120, at $241 \mathrm{ff}$.

131 a R.S.C. 1952, c. 314 as amended.

132 Galbraith, The New Industrial State 359 and 361 (1957).

18 op. cit. supra, n. 120, at 242.
} 
Perhaps the difficulties encountered in such a concept as white-collar crime are the products of a lack of imagination and willingness to seek solutions to social problems in other than traditional ways. The penal law has been a ready and ancient tool for this purpose but with each passing decade the weight of events are outstripping its capacity to cope. In short, conventional legal wisdom far too often becomes a trap rather than a springboard.

\section{ANOMIE}

The existence of factual inequality in a culture oriented towards an egalitarian ideology provides the basis for the theory of anomie as developed by Durkheim, the European, and Merton, the American. The spirit of revolt which this situation engenders provides another class oriented theory of crime and society.

Human ambitions are without limit and the North American dream apparently places few limits upon the means used to achieve success for individual ambitions. Success is measured in monetary terms, and those who fail are all too often by implication considered failures as human beings.

Equality of opportunity is a fundamental tenet of the egalitarian philosophy, and, in the words of Albert Camus, "the spirit of revolt can only exist in a society where a theoretical equality conceals great factual inequalities." If the achievement of success becomes a human need, and this success is measured in monetary terms, any discrepancy between the need and the means available for its satisfaction will provoke some reaction in the individual so frustrated. It is this reaction which leads to anomie or normlessness. The absence of limitations upon needs breeds a frustration with all limitations. Limitations of any kind are intolerable. "Under such conditions, religion loses most of its influence, and the government which should regulate the economy becomes its servant."134

Modern Western societies differ from other societies in that they allow and encourage alteration in their members status, and as has been pointed out they emphasize equality of opportunity. These societies however, differ in the emphasis they place upon goals and the manner of their achievement. In a society with strongly prescribed goals and sharp distinctions between orthodox and unorthodox means to them, the individual can adjust himself in four different ways. He can accept both the goals and the approved means to them-conformity. He may accept the institutionalized means but renounce ever achieving the goals-ritualism. He may renounce both goals and means-retreatism. Most frequently, next to conformity, he will accept and strive for the goals discarding institutionalized means in favor of unorthodox ones-innovation. It is in Merton's view, this innovative adjustment which can account for crime. Innovation in regard to the acquisition of material things may well lead to criminal conduct.

\section{ECOLOGY OF CRIME}

Considerable interest has been shown in the topographical distribution of crime. Comparisons of rates of criminal activity between defined

\footnotetext{
134 Op. cit. supra, n. 5 , at 501.
} 
areas of the city was the subject of Shaw's classical study of Chicago. ${ }^{135}$ Shaw observed that regardless of a declining population, and changes in its national, racial, and cultural composition, the highest rates of crime were maintained over a 25-year period in areas near the centre of the city of Chicago.

A discussion of the ecology of crime can best be carried out by referring to the roles of population density, mobility, rural and urban crime, delinquency areas, and housing conditions.

\section{(a) Population Density}

While early writers on the subject of population density and rates of crime rejected the notion that an increase in density meant an increase in rates of crime a recent study by Szabo of French crime statistics led him to conclude that there was a high positive correlation between density and crime. ${ }^{136}$

In Canada in 1966 the rates of offences known to the police per 100,000 of population in the following metropolitan areas were as follows: ${ }^{187}$

$\begin{array}{lr}\text { Montreal } & \mathbf{4 , 6 3 3 . 2} \\ \text { Toronto } & \mathbf{6 , 0 1 4 . 0} \\ \text { Vancouver } & \mathbf{1 0 , 5 8 3 . 1} \\ \text { Winnipeg } & \mathbf{5 , 9 7 6 . 1} \\ \text { Ottawa } & \mathbf{5 , 3 5 2 . 9} \\ \text { Hamilton } & \mathbf{7 , 3 8 2 . 8} \\ \text { Edmonton } & \mathbf{1 0 , 5 4 8 . 2} \\ \text { Windsor } & \mathbf{5 , 0 3 3 . 7} \\ \text { London } & \mathbf{9 , 1 9 3 . 7} \\ \text { Halifax } & \mathbf{7 , 9 1 4 . 3}\end{array}$

If the population density of these geographical areas was known it would then be possible to determine whether or not there was an significant correlation between that density and rates of crime. A rough conclusion can be drawn as to the correlation between population density and rates of crime from the fact that the rate of offences known to the police for all of Canada in 1966 was 5,406.3 per 100,000 of population. Cities such as Edmonton and Vancouver have approximately twice the national rate.

\section{(b) Mobility}

The relationship betwen physical and horizontal mobility, and crime and delinquency has been studied most effectively in Italy and the United States. Mannheim ${ }^{138}$ quotes the preliminary findings of the Italian study as stating:

At least as far as adults are concerned, migration does not appear to represent a criminogenic factor of social importance.

Savitz's Philadelphia study of migration and Negro children concluded that rates of criminality were higher for the Philadelphia born child than the migrant children. ${ }^{130}$

Comparisons of rates of crime between migrants and native born Canadians is possible making use of, among other things, information contained in the Annual Criminal Statistics. These statistics show the

135 Shaw, Delinquency Areas (1929).

136 Referred to in Mannheim, supra, $n$. 5, at 535

137 Dominion Bureau of Statistics, Ottawa, Crime Statistics 48-49 (1966).

138 Op. cit. supra, n. 5 , at 537.

139 Savitz, Delinquency and Migration in Wolfgang, Savitz, Johnston. The Sociology of Crime and Delinquency 199-205 (1962). 
country of birth of persons charged in any one year with indictable offences. If we were to determine the place of birth of all Canadians in Canada in that year we would then know the differing rates by country of birth. However, this evidence would not allow the drawing of any conclusions as to the criminogenic effects of migration. To do this, it would be necessary to determine the level of criminality of the migrant group in its country of origin and compare it with the level of criminality of the group after its arrival in Canada.

\section{(c) Rural and Urban Crime}

A discussion of rural and urban crime must keep in mind that the distinction is probably becoming of diminishing importance with the growing inter-penetration of rural and urban society with the anonymity of the city prevailing more and more. This anonymity coupled with increased exposure to opportunities for criminal behavior doubtlessly plays a large part in the increase in urban crime rates.

Reference may usefully be had to the comments on the subject made in The Challenge of Crime in a Free Society. ${ }^{140}$ Rates for most crimes are highest in the big cities. One in three robberies, and one in five rapes occur in cities of more than 1 million. The average rate for most crimes is twice as great in twenty-six core cities of more than 500,000 as in suburban or rural areas. The report notes that as a general rule "average rates increase progressively as the size of the city becomes larger." As business and industry increase in the suburbs, average crime rates increase as well. While rural rates are usually lower than city rates in regard to property crimes, the rates for offences against the person are more commensurate.

Dividing the 1966 Canadian population into those living in police metropolitan areas and those living in other areas we see approximately 38 per cent of the population living on the former and approximately 62 per cent in the latter. Yet, the percentage distribution of all Criminal Code Offences reported to the police is evenly divided. Thus, 38 per cent of the population of Canada apparently account for 50 per cent of the Code offences known to the police. ${ }^{141}$

\section{(d) Delinquency Areas}

A delinquency area is that portion of a city which becomes marked by characteristic patterns of anti-social behavior. Within this area various forms of criminal behavior is not frowned upon by the inhabitants, and hostility to the agencies of social control is a routine matter. A ghetto in a posture of defiance to the rest of the city is a suitable description.

Characteristic features of such an area are the pre-eminence of commercial and industrial activity, an area criminal tradition, bad housing, inadequate recreational facilities, peculiar child rearing practices, and enhanced opportunities for crime commission.

Two major studies have been carried out into the subject of delinquency areas: Shaw's study of Chicago, ${ }^{142}$ and Morris' study of Croydon. ${ }^{143} \mathrm{~A}$ conclusion implicit in both is that delinquency finds a congenial

$140 \mathrm{Op}$. cit. supra, n. 3, at $28 \mathrm{ff}$.

141 Crime Statistics, Chart E. 46 (1966).

142 Op. cit. supra, n. 135.

143 Op. cit. supra, n. 4. 
home among the poorer urban classes and that these classes have a marked tendency to be grouped together in well defined areas of our cities. Within these areas the norms of the larger society are conspicuous by their absence.

The drawing together of distinct social classes-lower, middle, and upper has the inevitable result of concentrating the lower classes into distinct physical proximity to each other. In part, this ingathering is fortuitous and in part it is the result of deliberately pursued governmental policies. This is particularly evidenced in the lack of government support for policies designed to house low income groups in predominantly upper and middle class areas. The concentration of low income housing units in distinct areas of cities which are usually the least desirable is surely evidence of a policy deliberately designed to promote a form of social segregation. The consequences of this ghetto building can be the creation of environmental conditions admirably suited to fostering antisocial behavior. ${ }^{144}$ The Winnipeg study also indicated that these areas of above average criminality were also characterized in a large part by above average rates of social disorganization based up the incidence of illigitimate births, infant mortality, suicides, tuberculosis, venereal disease, alcoholism, desertion, public welfare, child neglect, school dropouts, and mental illness. ${ }^{145}$

\section{Conclusion}

If man had no faith in his ultimate ability to explain phenomena rationally no science could exist. However, for a long period in his history he stopped short of attempting any rational explanation of human behavior and contented himself with viewing the springs of that behavior as inscrutable. This could not last, and it was inevitable that the successful methods of the evolving physical and biological sciences would tempt some to experiment with their application to the problems of human behavior. If man's environment was explicable by these methods was not man's actions within that environment explicable by these methods as well? A bold question, and a threatening one, for by the very asking of it assumptions of long standing become less firm, less certain. It may be that society instinctively fears that an answer to the questions "why is some conduct criminal, and why do some men behave criminally?" will only accentuate social strife, and not diminish it. Thus, perhaps there is a collective wish not to be informed.

However, in spite of this sentiment individuals deliberately, and occasionally by accident, add to our stock of answers to the questions which have been asked about man's behavior. Some of these men and their answers have been mentioned. The criminologist represents a group of questioners whose object is to explain, in a rational way, the phenomenon of crime. Thus, his claim to a place in the scientific spectrum. That he is a borrower of other men's flowers he does not deny. To the contrary, he emphasizes his position at the cross-roads of many disciplines.

14t See Winnipeg Social Service Audit, Interim Report, Community Characteristics, Social Disorganization, and Constituency Studies, Figure 20 (1967) 